$A D$

Award Number: DAMD17-97-1-7171

TITLE: Breast Cancer Associated Estrogen Receptors: Catechol Estrogen Receptors in ER-Minus Mice

PRINCIPAL INVESTIGATOR: Dennis B. Lubahn, Ph.D.

CONTRACTING ORGANIZATION: University of Missouri

Columbia, Missouri 65211

REPORT DATE: October 1999

TYPE OF REPORT: Annual

PREPARED FOR: U.S. Army Medical Research and Materiel Command Fort Detrick, Maryland 21702-5012

DISTRIBUTION STATEMENT: Approved for public release;

distribution unlimited

The views, opinions and/or findings contained in this report are those of the author(s) and should not be construed as an official Department of the Army position, policy or decision unless so designated by other documentation. 
For this collection of information is estimated to average 1 hour per response, including the time for reviewing instructions, searching existing data sources, gathering and maintaining

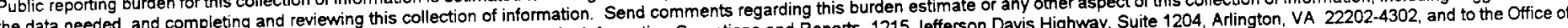
reducing needed, and completing and reviewing this colecto Directorate for Information Operation

reducing this burden to Washington Headquarters Services, Directorat, Washington, DC 20503

1. AGENCY USE ONLY (Leave blank)

October 1999
3. REPORT TYPE AND DATES COVERED

Annual (1 Sep 98-1 Sep 99)

\section{TITLE AND SUBTITLE}

Breast Cancer Associated Estrogen Receptors: Catechol

5. FUNDING NUMBERS

Estrogen Receptors in ER-Minus Mice DAMD17-97-1-7171

\section{AUTHOR(S)}

Dennis B. Lubahn, Ph.D.

\section{PERFORMING ORGANIZATION NAME(S) AND ADDRESS(ES)}

University of Missouri

Columbia, Missouri 65211

E-MAIL:

LubahnD@missouri.edu

9. SPONSORING / MONITORING AGENCY NAME(S) AND ADDRESS(ES)

U.S. Army Medical Research and Materiel Command

Fort Detrick, Maryland 21702-5012
8. PERFORMING ORGANIZATION REPORT NUMBER

\section{SUPPLEMENTARY NOTES}

12a. DISTRIBUTION / AVAILABILITY STATEMENT

12b. DISTRIBUTION CODE

Approved for public release; distribution unlimited

\section{ABSTRACT (Maximum 200 Words)}

Our research will lead to a better understanding of the developmental, physiological, and biochemical roles of endogenous and environmental estrogens in breast cancer causation, prognosis and treatment. We have found in ER- $\alpha$ minus mice a uterine lactoferrin mRNA response to the catechol estrogen, 4-hydroxyestradiol, but not to estradiol. We hypothesize that the putative 4-hydroxyestradiol receptor will elicit additional responses distinct from estradiol and the classic ER- $\alpha$ and ER- $\beta$ proteins. Using this mouse model system we propose to characterize the 4-hydroxyestradiol response and the putative 4hydroxyestradiol_receptor. Specifically, we propose to: Aim \#1 Characterize lactoferrin mRNA responses to 4-hydroxyestradiol in

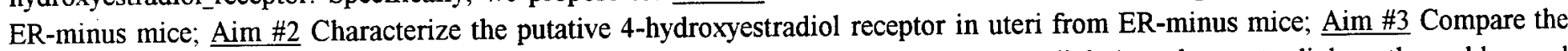
specificity of the responses to 4-hydroxyestradiol with those of estradiol, 2-hydroxyestradiol, 4-methoxyestradiol, methoxychlor, and tamoxifen in ER-minus mice; and Aim \#4 Clone the putative 4-hydroxyestradiol_receptor, which is different from both ER- $\alpha$ and ER- $\beta$. This new "estrogen" receptor is of major importance because of its potential involvement in novel pathways of estrogen responsiveness that may better explain estrogens' roles in breast tumor progression, prognosis, and therapy.

\begin{tabular}{|c|c|c|c|}
\hline \multicolumn{3}{|l|}{ 14. SUBJECT TERMS } & $\begin{array}{rr}\text { 15. NUMBER OF PAGES } \\
34\end{array}$ \\
\hline & 16. PRICE CODE \\
\hline $\begin{array}{l}\text { 17. SECURITY CLASSIFICATION } \\
\text { OF REPORT } \\
\text { Unclassified }\end{array}$ & $\begin{array}{l}\text { 18. SECURITY CLASSIFICATION } \\
\text { OF THIS PAGE } \\
\text { Unclassified }\end{array}$ & $\begin{array}{l}\text { 19. SECURITY CLASSIFICATION } \\
\text { OF ABSTRACT } \\
\text { Unclassified }\end{array}$ & $\begin{array}{l}\text { 20. LIMITATION OF ABSTRACT } \\
\text { Unlimited }\end{array}$ \\
\hline & & & 2 \\
\hline
\end{tabular}


FOREWORD

Opinions, interpretations, conclusions and recommendations are those of the author and are not necessarily endorsed by the U.S. Army.

Where copyrighted material is quoted, permission has been obtained to use such material.

Where material from documents designated for limited distribution is quoted, permission has been obtained to use the material.

Citations of commercial organizations and trade names in this report do not constitute an official Department of Army endorsement or approval of the products or services of these organizations.

$\checkmark$ In conducting research using animals, the investigator(s) adhered to the "Guide for the Care and Use of Laboratory Animals," prepared by the Comittee on Care and use of Laboratory Animals of the Institute of Laboratory Resources, national Research Council (NIH Publication No. 86-23, Revised 1985).

For the protection of human subjects, the investigator(s) adhered to policies of applicable Federal Law 45 CFR 46.

$\checkmark$ In conducting research utilizing recombinant DNA technology, the investigator(s) adhered to current guidelines promulgated by the National Institutes of Health.

$\checkmark$ In the conduct of research utilizing recombinant DNA, the investigator(s) adhered to the NIH Guidelines for Research Involving Recombinant DNA Molecules.

In the conduct of research involving hazardous organisms, the investigator(s) adhered to the CDC-NIH Guide for Biosafety in Microbiological and Biomedical Laboratories.

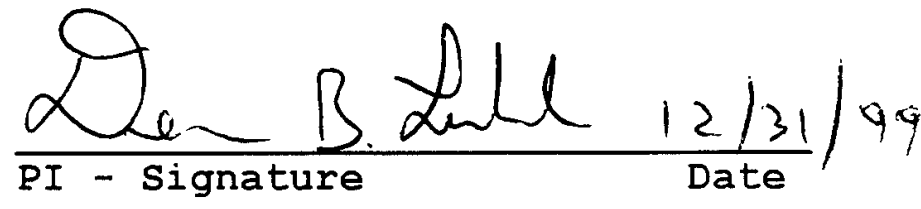




\section{Table of Contents}

Front Cover

SF 298, Report Documentation Page

Foreword

Table of Contents

Introduction

Body

Key Research Accomplishments/Progress

Reportable Outcomes

Conclusions

References

Appendix

One copy of a paper supported by this award. page 1

page 2

page 3

page 4

page 5

page 8

page 14

page 19

page 20

page 21

page 26 


\section{Award Number DAMD17-97-1-7171}

\section{Introduction:}

\section{Importance of Catechol Estrogen Responses in Human Breast Cancer}

Catechol estrogens have been studied extensively since enzymes capable of synthesizing them in vivo were discovered in the late fifties and early sixties. Their chemistry, biology, and potential functions have been well reviewed over the years (3-7). We will briefly review the importance and significance of catechol estrogens here. Catechol estrogens' structure and metabolism are diagrammed in Figure 1 below.

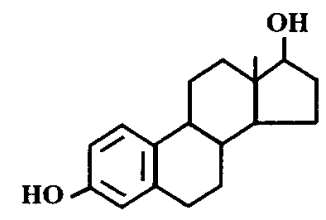

17ß-Estradiol
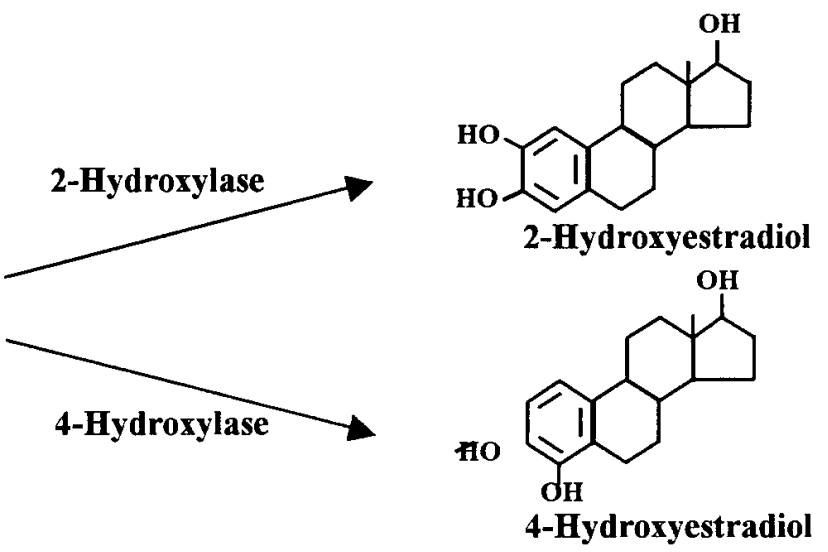

Figure 1. Metabolic conversion of $17 \beta$-estradiol to catechol estrogens: 2hydroxyestradiol and 4-hydroxyestradiol.

Investigating the overall mechanism of estrogens' actions through all their receptors is crucial in understanding breast tumor progression, prognosis, and therapy. Catechol estrogens have been found to be tumor associated in many studies of human breast cancer (Refs. 74-101), human uterine cancer (8), and hamster kidney tumor formation $(9,10)$. Their biological function is thought to be highly localized because of their rapid clearance from plasma (11). Ratios of 2- and 4-hydroxyestradiol concentrations vary between tissues because of differences in rates of synthesis and metabolism to their methoxy derivatives $(6-8,12)$. The tissue specificity data and the data presented in Preliminary Studies (102) strongly support the hypothesis that catechol estrogens are more than simple catabolic products destined for excretion, but have potentially important roles in human physiology and disease as ligands for as yet uncharacterized receptors. We hypothesize that the existence of the putative 4-hydroxyestradiol receptor has been masked, mainly because catechol estrogens will also bind and activate the classic ER protein $(13,14)$, which is present at relatively higher concentrations in humans.

\section{Candidate Proteins Involved in Non-Classical Estrogen Responses}

Candidate proteins fall into one, or possibly more, of the categories of estrogen response proteins listed in Table 1 on the next page. Proteins \#1 - \#12 are listed below the Table as candidates for the putative 4hydroxyestradiol receptor (4OHER), listed briefly for completeness, and/or listed for their potential as confounding factors in characterizing the putative 4-hydroxyestradiol receptor. 


\section{Table 1: Response Found with a Biologically Active "Estrogen" that is} Mediated by a Particular Type of Potential Estrogen Response Protein

\begin{tabular}{lccccc}
\hline & \multicolumn{5}{c}{${ }^{*}$ Types of Estrogen Response Proteins* } \\
“Estrogens" & A1(ER) & A2(ASER) & B1(NCER) & B2(40HER) & B3(MXCR) \\
\hline 17ß-Estradiol & Yes & $?$ & $?$ & No & No \\
4-Hydroxyestradiol & Yes & $?$ & $?$ & Yes & No? \\
Methoxychlor (metabolites?) & Yes & $?$ & $?$ & No? & Yes
\end{tabular}

[Other Natural Estrogens: Estrone,

Estriol, Other Catechol estrogens,

Flavones, Phytoestrogens. Yes

Yes ?

?

?

$?$

Synthetic Estrogens: Diethylstilbestrol,

Tamoxifen; Kepone, Some Other Pesticides,

Insecticides, Herbicides, etc.]

*Five Types of Estrogen Response Proteins*

A1. Classical Full Length Estrogen Receptor (ER) Protein Examples; Nuclear receptor from ER gene, also called ER-alpha membrane (non-genomic) receptor?, Welshons' non-translocatable receptor?,

A2. Non-classical Alternately Spliced Estrogen Receptor (ASER) Proteins Examples; Alternate splice form of A1, Shupnik's alternately spliced pituitary ER $m R N A$ coding for a novel protein? and potential alternately spliced protein, artifact in ER- $\alpha$ minus mice?

B1. Non-classical Estrogen Response (NCER) Proteins Examples; Gustafsson's ER-beta, Type II ER, tamoxifen receptor, other catechol estrogen receptors / orphan receptors (G-protein / 7 transmembrane or steroid receptor super families)?, Welshons' non-translocateable receptor?, c-erbB2, membrane (non-genomic) receptor?

B2. Putative 4-Hydroxyestradiol Receptor (4-OH ER) Protein

B3. Putative Methoxychlor Receptor (MXCR) Protein Includes receptors for possible methoxychlor metabolites that may be mediating responses.

\section{Table 1 Footnote:}

\section{Description of potential estrogen response protein candidates (\#1-\#12)}

1) Classic, wild-type, full length ER (or Type AI) protein

In general, non-classical, genomic estrogen response pathways potentially involve at least one of the non-ER proteins (described below). Additional, non-classical, non-genomic estrogen response pathways (15-18) that may be mediated through the classic ER protein or other non-ER proteins are not part of this proposal.

2) Catechol estrogen "receptor(s)" - (Putative 4-hvdroxpestradiol receptor?)

Catechol estrogens are produced by the hydroxylation of the 2 and 4 positions of estradiol (see Figure 1. page 20). While catechol estrogens bind to the classic ER with high affinity $(14,15), 17 b$-estradiol does not bind to a partially purified membrane "catechol estrogen" receptor (19). Because of this lack of $17 b$-estradiol binding, the fascinating literature suggesting novel functions for catechol estrogens (reviewed earlier) and most importantly, the responses seen with 4-hydroxyestradiol in the ER- $\alpha$ minus mice (see Preliminary Studies section), we also hypothesize that a unique receptor for catechol estrogens may exist. Methoxychlor metabolites are known that contain the catechol structure of two adjacent hydroxyls on an aromatic ring (20). Because of the similarities in chemical structure, it is possible to speculate that a methoxychlor metabolite might also bind to a putative catechol estrogen receptor. Proposed competition studies would allow us to examine this question (see Specific Aim \#2).

3) Jan-Ake Gustafsson's Estrogen receptor - beta

ER-beta, a novel member of the steroid receptor super family, has been cloned by Gustafsson et al. (personal communication, 21,22). Homology of ER-b to the classic estrogen receptor (now termed ER-alpha) is $17 \%$ in the $N$ - 
Lubahn: ER-minus mice terminal region, $96 \%$ in the DNA-binding domain, $29 \%$ in the hinge region, and $55 \%$ in the estradiol-binding domain. ER-beta expressed in rabbit reticulocyte lysates binds to estradiol with an affinity of $0.6 \mathrm{nM}$. It is 485 amino acids long with a molecular weight of 54,000 daltons and can activate transcription through an estrogen response element. ER-b is found in rat prostate from which it was cloned, primarily in the epithelial cells (ER-a is primarily in prostate stromal cells), in the uterus, and in most other tissues but not in mammary gland or in the breast cancer cell lines, MCF-7, ZR75 or T47D. In uterus ER-beta seems to be present at 5-10\% of the concentration of classic ER. We are now checking, as is likely, to see if this explains the residual estradiol-binding activity found in the ER- $\alpha$ minus mice. Unique binding characteristics to distinguish ER-alpha and -beta have not yet been released. The lack of inhibition by estradiol and ICI of the 4-hydroxyestradiol response excludes ER-beta as a candidate for the putative 4-hydroxyestradiol receptor (21,22, 102 - see Appendix).

\section{4) Orphan receptors of the Steroid Receptor Superfamily, ERR1 and ERR2}

The estrogen-related receptors 1 and 2 (ERRI and ERR2) have limited homology to the ER gene and are not reported to bind estrogens (catechol estrogens, methoxychlor and kepone are not mentioned) (23). Their native ligands are unknown (hence the name orphan receptors) and, except for their homology to ER, they have no known functional connection to estradiol. Because a response has been observed to 4-hydroxyestradiol, methoxychlor and kepone in ER- $\alpha$ minus mice, we must seriously consider that the putative receptors to which they bind may be orphan members of the steroid receptor superfamily. Homology to a known steroid-binding gene family would allow the screening of cDNA libraries under low stringency conditions and would enable additional candidate genes for the putative methoxychlor receptor, like ERRI and ERR2, to be cloned, expressed, and analyzed (see Specific Aim \#4).

\section{5) Membrane estrogen receptor or binding protein}

Despite nearly 30 years of reports it is only recently that a "membrane estrogen receptor" has gained qualified acceptance (24). Evidence for membrane estrogen receptors come from reports based on biochemical isolation (25-27), immunocytochemistry (28), fluorescent labeled estradiol (29,30) and estrogen immobilization on an inert support (31). It is not clear that these all represent the same protein because of the widely divergent techniques used in the analyses.

\section{6) Type II Estrogen Receptor}

This low affinity estrogen binding protein with a binding affinity lower than the classic ER has been the subject of recent successful purification reports $(32,33)$. The type II ER is $73 \mathrm{kd}$ in size with a $\mathrm{Kd}$ for estradiol of $24 \mathrm{nM}$. The $E R-\alpha$ minus residual uterine estradiol-binding activity (see \#10) appears not to be Type II ER because of its $0.2 n M K_{d}$ for estradiol $(1,2)$.

\section{7) Putative Tamoxifen Receptor}

There exists a tamoxifen-binding protein that is distinguished from the classic ER on the basis of binding specificity studies (34-36). Estradiol has little or no affinity for this "tamoxifen" receptor (34). In preliminary experiments we have not found any biological responses to tamoxifen in the ER- $\alpha$ minus mice; unlike methoxychlor. kepone or 4-hydroxyestradiol, tamoxifen does not induce lactoferrin mRNA.

\section{8) Welshons' non-translocatable cvtoplast ER}

Currently there is a form of estrogen receptor that is not found in the nucleus after estrogen stimulation in estrogen-sensitive breast cancer cells (37). Present evidence suggests a post-translationally modified ER, perhaps positioned to mediate non-classical, non-genomic effects.

\section{9) c-erbB2, also called neu or HER2}

There has been a surprising recent report, unconfirmed as far as 1 know, that the protooncogene, c-erbB2 binds estradiol with a $2.7 \mathrm{nM} \mathrm{K}$ (38). This protein is a $185 \mathrm{kd}$ transmembrane glycoprotein similar to the EGF receptor. Estradiol is reported to activate the tyrosine kinase activity of c-erbB2 and down regulate this protein.

\section{0) Residual Uterine Estradiol-Binding Activity Found in ER-a Minus Mice (Artifact?)}

Recent work from our own lab has demonstrated that Gustafsson's ER-beta is the likely source of most of the 5$10 \%$ residual uterine estradiol-binding activity $(1,2)$ and not $E R$-a, since that is the level that has been reported for ERbeta in the uterus $(21,22)$. No classic estradiol responses potentially mediated through this residual activity have yet been found $(1,24)$ although differential display suggests they exist (data not shown).

\section{1) Shupnik's translation product (ASER) from alternately-spliced pituitary ER mRNA}

This alternately spliced form of ER $m R N A$ is present in high levels in rat pituitary $(39,40)$. We have made the necessary oligonucleotides and will use them to look for an ASER mRNA in the ER- $\alpha$ minus uterus and pituitary. (No resources were requested for these studies in this proposal.) 
Lubahn: ER-minus mice

\section{2) A novel NCER protein}

A completely novel NCER protein might be detected in the homozygous ER- $\alpha$ minus mice. A lack of homology to other known receptors when attempting to clone a completely novel, putative 4-hydroxyestradiol receptor (See Aim \#4) would require isolation and cloning techniques that utilized affinity chromatography or expression cloning.

\section{Body:}

\section{Cell-Type Specific Uterine Expression of Lactoferrin (LF) Gene in ER- $\alpha$ minus Mice} Exposed to Estradiol-17ß, Methoxychlor, Kepone, or 4-Hydroxyestradiol (4-OH-E 2 )

Early experiments were performed to examine whether uteri of homozygous ER- $\alpha$ minus mice mutated for the ER gene respond to various estrogenic compounds (102, 103, see Appendix for a copy of 103). Estrogenic compounds examined were estradiol-17 $\beta$ (primary estrogen), methoxychlor (41-43, 102), kepone (44), and 4-hydroxyestradiol a catechol estrogen. Additional experiments were carried out using tamoxifen and ICI-182,780 (antiestrogens), and ICI-182,780 in conjuction with estradiol-17 $\beta$ or 4-hydroxyestradiol.

Surprising and exciting results were observed. Consistent with previous findings (2), treatment with estradiol-17 $\beta$ failed to induce the LF gene in the uterus of ovariectomized ER- $\alpha$ minus mouse. However, to our surprise, treatments with 4-OH-estradiol-17 $\beta$, methoxychlor (103), or kepone induced the expression of this gene in the uterine epithelium of ovariectomized ER- $\alpha$ minus mice; the expression was most prominent in the luminal epithelium. These results have been verified via quantitative PCR $(102,103)$. Treatment with the ERspecific antagonist, ICI-182,780 alone $(45,46)$, did not influence this uterine gene. However, again to our surprise, ICI-182,780 did not interfere with the induction of the LF gene by 4-OH-estradiol. Because estradiol is non-responsive, it also was used in competition experiments with 4-OH-estradiol-17 $\beta$, where it was also unable to interfere with LF induction.

Additional control experiments with the COMT (catechol O methyl transferase) inhibitor, U-0521, (47) have shown that it does not stimulate LF mRNA induction. This is important because catechol estrogens are capable of inhibiting COMT, which is necessary for the inactivation of dopamine, a catecholamine. Increased local dopamine levels might induce LF mRNA synthesis through the catecholamine receptors. The lack of effect by a COMT inhibitor indicates that 4-hydroxyestradiol is not acting indirectly to stimulate LF mRNA induction. In addition, since COMT alone does increase active dopamine levels, the likelihood is decreased that the lactoferrin response is mediated through a catecholamine receptor.

These results suggest the presence of a signaling pathway that is not mediated via the conventional ER, but rather by the putative 4-hydroxyestradiol receptor. (The competitive inhibition results of 4-hydroxyestradiol with estradiol or ICI-182,780 are very important because they tend to exclude any confounding problems with the ER- $\alpha$ minus residual uterine estradiol-binding activity / Gustafsson's estradiol-binding ER-beta $(21,22)$.) These results suggest that an acute treatment with 4-hydroxyestradiol induces the LF gene in a cell-type specific manner in the mouse uterus. In recent results, we have confirmed the original results with lactoferrin mRNA and also observed that glucose 6 phosphate dehydrogenase is also induced in ERa-minus mice uterus by methoxychlor but not by estradiol (103).

\section{Hypothesis/Purpose:}

4-Hydroxyestradiol and other biologically important estrogens work, not only through the classic ER protein, but also through their own unique non-ER receptors. These receptors can be readily characterized in an ER- $\alpha$ minus mouse background. Specifically, estrogen responses in the uterus and mammary gland are not mediated exclusively by the classical ER protein but in addition by specific types of non-classical estrogen response (NCER) proteins. Characterization of estrogen responses and NCER proteins in ER- $\alpha$ minus mice will lead to a fuller understanding of the physiological and pathological roles of all estrogens in breast cancer. 


\section{Original Technical Objectives/Specific Aims:}

The first estrogen responses found in ER- $\alpha$ minus mice are to 4-hydroxyestradiol (a catechol estrogen), methoxychlor, and kepone. We are proposing initially to characterize the 4-hydroxyestradiol response and the putative 4-hydroxyestradiol receptor, because of the importance of catechol estrogens in breast cancer.

Specifically, this grant proposes experiments to:

Specific Aim \#1. Characterize lactoferrin mRNA responses to 4-hydroxyestradiol in ER- $\alpha$ minus mice

Specific Aim \#2. Characterize the putative 4-hydroxyestradiol receptor in ER- $\alpha$ minus mice.

Specific Aim \#3. Compare the specificity of the responses to 4-hydroxyestradiol with those of estradiol, 2-hydroxyestradiol, 4-methoxyestradiol, methoxychlor, and tamoxifen in ER- $\alpha$ minus mice.

Specific Aim \#4. Clone the putative 4-hydroxyestradiol receptor (4OHER).

\section{Experimental Design / Methodology:}

Hypothesis \#1: Lactoferrin will respond to 4-hydroxyestradiol through a receptor-mediated pathway. Specific Aim \#1.

Characterize lactoferrin mRNA responses to 4-hydroxyestradiol in ovariectomized (ovex), ER- $\alpha$ minus mice.

1a. In vivo uterine characterization of lactoferrin induction via in situ hybridization analysis.

i. Dose response by within-run computer image analysis (Ambion)

ii. Specificity by comparison of 4-hydroxyestradiol responses with these 5 compounds: estradiol,

2-hydroxyestradiol, 4-methoxyestradiol, methoxychlor, and tamoxifen

1b. In vivo tissue specificity and quantitation of lactoferrin mRNA response to 4-hydroxyestradiol via in situ hybridization analysis and quantitative PCR. Examine uterus and mammary gland.

\section{Rationale:}

1a. Characterization of lactoferrin mRNA response to 4-hydroxyestradiol provides potential clues about purification and function of the putative receptor for 4-hydroxyestradiol. A dose response curve will be obtained in vivo then in vitro to get an estimate of the physiological/pharmacological concentration range of 4hydroxyestradiol. This will give us a rough idea about the putative receptor binding constant. Two of the six compounds, 4-hydroxyestradiol and methoxychlor, were chosen because they elicit responses in ER- $\alpha$ minus mice. The catechol estrogen, 4-hydroxyestradiol, is made from estradiol by a hydroxylase and methoxychlor is known to be metabolized to a catechol (20). 2-Hydroxyestradiol is usually found in varying rations where 4hydroxyestradiol is made (See Figure 1). 4-Methoxyestradiol is considered to be an inactivated form of 4hydroxyestradiol. However, this 4-methoxy form is less active only with ER; it is not clear if it will also be inactive with 4OHER. 2-Hydroxyestradiol and 4-methoxyestradiol if unresponsive, as well as estradiol, tamoxifen, and ICI-182,780 will be used in competition studies to roughly determine the specificity of the receptor response.

1b. Determination of lactoferrin mRNA expression in various tissues after 4-hydroxyestradiol exposure will provide information about the receptor's tissue distribution. Tissues to be checked express lactoferrin (4850). Quantitation will be by quantitative PCR. If possible, a response in a primary uterine culture would rule out an indirect endocrine action of 4-hydroxyestradiol.

\section{Experimental Design / Methods / Expected Results / Potential problems:}

1a. Steroids are from Steraloids Inc. (Wilton, NH); ultrapure methoxychlor is from Radian (Austin, TX). In situ hybridization will be performed to determine the dose response of methoxychlor induction of uterine lactoferrin mRNA. Initial doses will be one oral dose in oil followed by a 24-hour interval of $500 \mathrm{ng}, 5 \mathrm{ug}, 50 \mathrm{ug}$, $500 \mathrm{ug}$, and $5 \mathrm{mg}$ per 30 gram mouse. If it does not appear saturable, we will try to go to $50 \mathrm{mg}$. A time course, from 2 hours after the last optimal dose from above, will be extended out until values return to background. This will determine the rate of the reversibility of the response. Estradiol, 2-hydroxyestradiol, 4-methoxyestradiol, methoxychlor, tamoxifen, and ICI-182,780 will be used individually (doses determined by dose response curve) and in combination (at 100 fold excess) with 4-hydroxyestradiol to determine if they will stimulate or inhibit the response and are working through the same receptor mechanism. 
Lubahn: ER-minus mice

1b. The listed tissues express lactoferrin (48-50) and will be examined by in situ hybridization for responses at the optimal dose found in uterus. These optimally responding tissues will be examined for dose response to roughly compare their binding and response parameters with the uterine receptor.

Hypothesis \#2: There is a unique receptor for 4-hydroxyestradiol distinct from ER- $\alpha$ and ER- $\beta$. Specific Aim \#2.

Characterize the putative 4-hydroxyestradiol receptor in uteri from ER- $\alpha$ minus mice.

2a. Localization by subcellular fractionation

2b. Analyze for saturable binding, binding affinity, and ligand specificity

2. Rationale / Experimental Design / Methods / Expected Results:

A receptor by definition must display low capacity, saturability, and specificity with a binding affinity consistent with its dose response curve. Thus, binding studies with $\left[6,7-{ }^{3} \mathrm{H}\right]-4$-hydroxyestradiol will be performed by whole cell uptake in primary uterine culture. Competition studies will be performed with estradiol, 2-hydroxyestradiol, 4-methoxyestradiol, methoxychlor, tamoxifen, and ICI 182,780 to demonstrate specificity. 2Hydroxyestradiol and 4-methoxyestradiol will be used because they are estradiol metabolites and are found wherever 4-hydroxyestradiol is found. Similarly, methoxychlor is also known to have catechol and methoxy metabolites (20). It is possible that catechol estrogens and methoxychlor may share the same non-ER receptor as well as being capable of activating ER. Unique binding specificity will allow us to utilize wild type swine or bovine abattoir sources to purify the 4-hydroxyestradiol receptor away from any unique estradiol-binding protein or wild type ER protein. Subcellular fractionation studies will be done to help determine which type of receptor super family the putative methoxychlor receptor belongs. If the receptor is nuclear or cytoplasmic, and not found in the membrane, it is more likely to be a member of the steroid receptor super family. Binding affinity and specificity (competition) studies will be performed with ${ }^{3} \mathrm{H}$-catechol estrogens synthesized and purified in our labs.

Hypothesis \#3: The 4-hydroxyestradiol receptor will induce unique \& specific responses distinct from both estradiol and 4-hydroxyestradiol action through ER- $\alpha$ and ER- $\beta$. These are best found by utilizing ovex, ER- $\alpha$ minus mice.

Specific Aim \#3.

Messenger RNA responses to 4-hydroxyestradiol will be compared with those potentially observed with estradiol, 2-hydroxyestradiol, 4-methoxyestradiol, methoxychlor, and tamoxifen in the following assays:

3a. Differential display PCR in ER- $\alpha$ minus uteri treated with the 6 listed estrogens/compounds.

3b. Northern \& in situ hybridization analysis for candidate mRNA responses, like progesterone receptor and glucose-6-phosphate dehydrogenase in uterus, mammary gland, and other selected tissues.

\section{Rationale/Experimental Design/Methods:}

Time course and dosage regimens will be as described earlier. Select mRNA candidates will be analyzed for their response to the 6 listed compounds. Candidate mRNA responses include lactoferrin, cox-1, progesterone receptor and glucose-6-phosphate dehydrogenase (51); others may be substituted depending upon the results of differential display PCR or subtractive hybridization. These mRNAs have been chosen, because they are known to respond to estradiol in uterus (2) (and therefore are estrogenic responses) and because we have shown that the first two respond to 4-hydroxyestradiol in ER- $\alpha$ minus uterus where estradiol does not invoke a response. Primarily we will examine the uterus and mammary gland for responses, but other tissues will be frozen away and examined, if other funding becomes available.

\section{Expected Results/Potential problems:}

Responses to 4-hydroxyestradiol and methoxychlor are expected. Estradiol, 2-hydroxyestradiol, 4methoxyestradiol, and tamoxifen are potentially responsive. From our preliminary data with the ER antagonist, ICI 182,780 , it is not expected that estradiol will also work through the putative 4-hydroxyestradiol receptor. However, estradiol, methoxychlor, and tamoxifen are capable of being metabolized to catechols, which could also induce responses. We, of course, expect to see this metabolism but it should alter the same mRNAs detected 
by in situ hybridization or DDRT-PCR as 4-hydroxyestradiol. Time course experiments and HPLC checks for metabolism of estradiol will be essential (See Figure 1).

Hypothesis \#4: The 4-hydroxyestradiol receptor protein can be cloned by sequence homology because it is likely to be a member of the steroid receptor super family. Alternatively, the 4-hydroxyestradiol receptor cDNA can be isolated by expression cloning or sequence obtained from receptor protein affinity purification.

\section{Specific Aim \#4.}

\section{Clone the putative 4-hydroxyestradiol receptor}

4a. Test for 4-hydroxyestradiol binding and responses through Gustaffson's ER-beta.

4b. Screen for receptors that change concentration by differential display PCR analysis in the steroid receptor families using anchored oligonucleotide primers.

4c. Screen uterine ER- $\alpha$ minus mouse cDNA library with probes from conserved sequences of the steroid receptor super family via low stringency hybridization.

4d. Test expressed candidate orphan receptor cDNAs for binding to 4-hydroxyestradiol.

4e. Expression cloning using $\left[{ }^{3} \mathrm{H}\right]$ - 4-hydroxyestradiol.

4f. Purification by affinity chromatography, then obtain partial peptide sequence for raising epitope specific antibodies or synthesizing oligonucleotide probes for screening of ER- $\alpha$ minus cDNA libraries.

4g. After full-length cDNA clone isolation and sequencing from one of the approaches above (a-f) we will confirm or verify identity of putative receptor by:

i. in vitro expression and binding to labeled 4-hydroxyestradiol, or

ii. testing for transcriptional activation of a lactoferrin promoter reporter construct

(or other 4-hydroxyestradiol-responsive promoter) with the receptor bound to 4-hydroxyestradiol.

4h. Tissue specific localization of 4-hydroxyestradiol receptor mRNA expression will be ascertained by RT-PCR, Northern blot analysis, or in situ hybridization.

\section{Rationale / Experimental Design / Methods:}

To better elucidate the function of the 4-hydroxyestradiol NCER protein (putative 4-hydroxyestradiol receptor or 4OHER), we must isolate and clone its cDNA. For thoroughness we will need to check the binding of 4-hydroxyestradiol to Gustafsson's expressed ER-beta clone (22) which we have PCR amplified from mouse. 4-Hydroxyestradiol binding ability and/or transcriptional induction characterization of any NCER protein is essential for verification that we have isolated the correct receptor protein. For expression cloning, we will need a way to distinguish the NCER protein from the ER protein, hopefully by their steroid binding characteristics. Thus, detailed specificity, saturability and affinity binding studies will be needed from Specific Aims \#1 and \#2.

An unpublished, but highly successful method utilized by the PI in the isolation of orphan steroid receptors, is to utilize differential display PCR with anchored oligonucleotides from highly conserved regions from the gene family one is trying to clone, rather than the normal anchored oligos from the poly A tail. The twist here is to utilize DDRT-PCR rather than simple degenerate or low stringency PCR, because then one can screen only for mRNAs that change in concentration after 4-hydroxyestradiol exposure. Because, most steroid receptors down regulate their own mRNA levels, this allows one to distinguish the 4-hydroxyestradiol receptor sequence from other members of its gene family which will have very similar sequences. This is a significant problem because some gene families, like the steroid/nuclear receptor families, contain over a hundred members.

The most widely used procedure with which we have a great deal of experience is the screening of libraries with low stringency probes or PCR amplification under low stringency conditions. The probe used will be from the first zinc finger of the DNA-binding domain of the steroid receptor super family, similar to what the PI utilized in the cloning of the androgen receptor gene and cDNA (52-54).

Candidate cDNA approaches using the proteins discussed in Footnote Table 1, (ERR1 and ERR2) also will be tested because of their homology to the estrogen receptor. An alternative procedure to clone the putative 4-hydroxyestradiol receptor would be to prepare ER- $\alpha$ minus uterine cDNA expression libraries in mammalian cells and screen for $\left[{ }^{3} \mathrm{H}\right]$ - 4-hydroxyestradiol -binding activity (55-57).

While affinity column purification is a potential approach, it is not being proposed as the primary approach, because of both the probable low amounts of activity and the higher efficiency of other approaches. 
Lubahn: ER-minus mice However, an affinity column made from a 4-hydroxyestradiol derivative would likely bind to the ER protein (14). This ER binding to the column could be blocked with estradiol and then an easily obtained abattoir source of receptor from pig or cow uterus would be used. Using this abattoir source to obtain sufficient quantities of purified protein for amino acid sequencing and/or antibody preparation will be difficult, but we do have experience in this type of purification (53). Oligonucleotides generated from protein sequence data or antibodies raised against the NCER protein (or synthetic peptide fragments) will allow cloning of the NCER cDNA from a library for further studies $(52,54)$.

Finally, we will need to express the protein and demonstrate its 4-hydroxyestradiol-binding characteristics or transcriptional activation ability to confirm that we have cloned the correct receptor. Localization by in situ hybridization would confirm functional response data from Aim \#1 and potentially lead to additional tissues capable of responding to 4-hydroxyestradiol.

\section{Expected Results/Potential problems:}

A 4-hydroxyestradiol receptor clone will be isolated that is a member of the steroid receptor super family. ER-beta is unlikely to be the 4-hydroxyestradiol receptor because ER-beta can bind and be activated by estradiol and the 4-hydroxyestradiol response was not affected by estradiol competition (preliminary data not shown). Studies of 4-hydroxyestradiol binding to ER-beta and of 4-hydroxyestradiol activation of transcription are needed to determine if ER-beta is mediating the actions of methoxychlor.

Potential problems are legion in the cloning of any novel receptor, but standard biochemical and molecular biology techniques (which the PI is familiar with) are available to surmount them. Subcellular localization will help determine if it is a nuclear receptor. However, if it should localize to the nucleus and/or happen to not be a member of the steroid receptor super family, then approaches $4 \mathrm{e}$ and $4 \mathrm{f}$ should still be viable. Prioritization of effort will be to try approaches $4 \mathrm{a}, 4 \mathrm{~b}, 4 \mathrm{c}$, then $4 \mathrm{~d}$ before going to $4 \mathrm{e}$. Then finally, if necessary, we will develop and utilize an affinity column approach (4f).

\section{General Methods:}

\section{Procedures for In Situ Hybridization Analysis}

(To study estrogen responses, we examined the cell-type specific expression of the LF gene in the mouse uterus by in situ hybridization $(58,59)$ in collaboration with SK Dey and SK Das, UKMC (102). In control experiments wild type, ovariectomized mice (C57BL/6) were given a single injection (sc) of oil $(0.1 \mathrm{ml} / \mathrm{mouse})$, estradiol-17ß (250 ng/mouse), kepone $(15 \mathrm{mg} / \mathrm{kg})$, the antiestrogen ICI-182,780 (50 ug/mouse) or the same dose of $E_{2} 30 \mathrm{~min}$ after an injection of the same of ICI. Mice were killed $12 \mathrm{~h}$ after the last injection and their uteri collected for in situ hybridization.

\section{Labeling and Purification of Catechol Estrogens}

Radioactive chemicals are obtained from Dupont NEN (Boston, Massachusetts). Hexa-labeled [6,7- $\left.{ }^{3} \mathrm{H}\right]-$ estradiol is enzymatically treated with human cyp1b1 (4-hydroxylase) with NADPH as a cofactor (60). Since both 2- and 4-hydroxyestradiol (primarily the later) are produced in this system, labeled catechol estrogens are separated and purified by HPLC in Wade Welshons' laboratory (60). Catechol estrogens have stability problems due to oxidation and must be purified by HPLC before use (60). Stability of the labeled catechol estrogens is preserved by addition of $10 \mathrm{mM}$ ascorbic acid to all buffers.

\section{$\left.{ }^{3} \mathrm{H}\right]$-Estradiol or $\left.]^{3} \mathrm{H}\right]-4$-hydroxyestradiol binding assay}

Sexually mature mice of each ER genotype are ovariectomized and 7 days later cytosol and nuclear extracts are prepared. Aliquots of each are assayed for $\left[{ }^{3} \mathrm{H}\right]$-estradiol or $\left[{ }^{3} \mathrm{H}\right]$-4-hydroxyestradiol binding as described previously (61). For normalization of binding data, DNA content of the nuclear fraction is measured using the procedure of Labarca and Paigen (62). 


\section{Preparation of mouse uterine cells for primary cell culture.}

Immature or ovariectomized female ER- $\alpha$ minus or wild type mice are utilized in the isolation of uterine cells (24). Estrogen-free growth medium is replaced with fresh growth medium the day after plating. Medium is changed again the two days prior to experimentation.

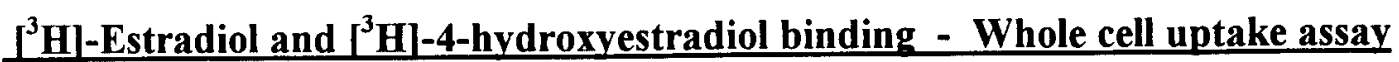

This binding assay is performed according to the method of Welshons et al. $(41,63)$. Cells will be incubated at $37^{\circ} \mathrm{C}$ in medium labeled with $\left[{ }^{3} \mathrm{H}\right]$ estradiol or $\left[{ }^{3} \mathrm{H}\right]-4$-hydroxyestradiol in the presence (nonspecific binding) or absence (total binding) of a 100 -fold excess of unlabelled ligand. For normalization of binding data, well content of DNA and protein are measured, using the procedures of Labarca and Paigen (62) and Bradford (64) respectively.

\section{Differential display reverse transcriptase PCR (DDRT-PCR) analysis of mRNA}

DDRT-PCR is a powerful tool for the analysis of subtle changes in gene expression in tissues and cell lines (65). Early use of this technique has had mixed success in laboratories around the world, but with improvements in methods it has become more reliable (66). This technique allows detection of differentially expressed genes without using specific probes for known gene products and is ideally suited to our purposes of detecting potential subtle 4-hydroxyestradiol, methoxychlor or estradiol, as well as other estrogens, responses in ER- $\alpha$ minus mice. RNA is isolated using a kit (Purescript RNA Isolation Kit) obtained from Gentra Systems, Inc. (Minneapolis, MN). Differential display of mRNA is examined using a kit obtained from GenHunter Corporation (Brookline, MA) (65-67). Steroid-regulated gene expression can ideally be studied by DDRT-PCR because there are relatively few changes in gene expression that occur. The PI has in the past successfully used the technique with "diabetic" tissue culture cell models to isolate novel glucose-responsive orphan steroid receptors from diabetic model cell lines (data not shown, 68). The method is more reproducible in vitro culture than in vivo, but with three separate uteri, each being run in duplicate, (6 samples per treatment) we reduce our problems with false positives. However, differentially expressed mRNA bands, which are isolated, cloned into plasmids, and expression changes must be confirmed by analysis as probes on Northern gels, by in situ hybridization, or by quantitative PCR. After confirmation and sequencing, these probes are used as markers of differential gene expression due to the presence or absence of ER or a particular estrogen treatment.

Quantitation of LF mRNA levels by RT/competitive polvmerase chain reaction of the Effects of Estradiol, Kepone or 4-Hydroxyestradiol on Uterine Lactoferrin mRNA levels in Ovariectomized Wild Type or ER$\underline{\alpha}$ Minus Mice

Construction of the mutant templates (See Reference 103 in Appendix for details).

To perform a competitive PCR for LF mRNAs, a mutant template (the competitor), containing the same primer template sequences as those of target cDNA competing for primer annealing and amplification, is generated by introducing a non-specific DNA fragment into a mouse LF cDNA clone (71). A 185 bp blunt-ended fragment (SspI) obtained from pGEM7Zf $(+)$ vector, was ligated with the LF cDNA in pGEM4Z at the StuI site. This DNA construct was used to serve as a competitor template to carry out the quantitation of LF mRNA levels in uterine tissues.

RT and competitive PCR.

Total RNA (1 $\mu \mathrm{g})$ was reverse-transcribed using an antisense oligo (5') GGAACACAGCTCTTTGAGAAGAAC 3') for mouse LF mRNA. The protocol for the RT reaction, for the PCR reaction and the cycle parameters have been described (72). The competitive PCR was performed using the method as described (73). In brief, a fixed amount (1/10th) of the total RT product and increasing amounts (10fold serial increases) of the mutant template are co-amplified for 30 cycles by PCR, using the mixture of sense ( $5^{\prime}$ AGGAAAGCCCCCCTACAAAC 3') and antisense (as shown above) oligos. The PCR amplified products were analyzed by Southern hybridization using a 32P-end labeled internal oligo (5' CTGCTGTTCTTCACGACTGCTACC 3'). Direct radioimaging of the Southern blot was performed by Ambis 
image analysis system to estimate the radioactive intensity of the bands of the target cDNA (276 bp) and competitor cDNA (461 bp). The ratio of band radioactive intensities of the competitor and target cDNAs was calculated for each sample and plotted against the amounts of competitor. The amount of target cDNA is determined from the logarithm plot at zero equivalence point. The efficiency of RT reaction was controlled by measuring the ribosomal protein L-7 (rpl7) mRNAs levels in each sample.

\section{Molecular Biology / Genetic Procedures}

Standard procedures will be utilized unless specifically modified as indicated $(69,70)$.

\section{Key Research Accomplishments/Progress}

\section{New Timetable for the proposed experiments:}

The diagram below outlines likely emphasis over the remaining years of support.
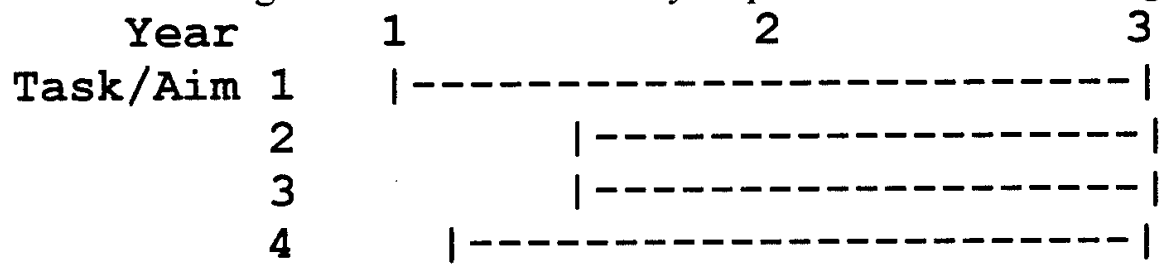

\section{Progress on Tasks:}

Task/Specific Aim \#1. Characterize lactoferrin mRNA responses to 4-hydroxyestradiol in ER- $\alpha$ minus mice. Specificity and dose response.

Progress:

1998 Ongoing. A paper has been published describing the specificity of lactoferrin mRNA response to 4OHE2 (102). We have had a surprisingly hard time getting RNA from mouse tissues uncontaminated by lactoferrin amplified DNA so that we can do the dose response for 4-hydroxyestradiol. It should be possible because we were able to get a nice saturable dose response curve for methoxychlor which may be acting through a catechol mechanism as well (103). We are likely to replace the in situ approach with a Taq Man quantitation approach because of the ease of analysis and the more quantitative nature of this new technique.

1999 Ongoing. We have had a difficult time obtaining reproducible results from RNA isolated from 4hydroxyestradiol-treated mouse uterine tissues. This has been a prevalent problem especially among ER $\alpha$ KO mouse uterine tissues. However, we believe this problem to be related to RNA concentration, and not RNA isolation technique, given the extremely small size of the ER $\alpha$ KO mice uteri. Consequently, ER $\alpha$ KO mice uteri will be pooled for a given treatment group (e.g., specific 4-hydroxyestradiol dose, specific 4-hydroxyestradiol treatment time) in order to generate both a dose response curve and time course curve for 4-hydroxyestradiolinduced uterine lactoferrin mRNA response. Although in situ hybridization and/or quantitative RT-PCR were originally proposed as methods for lactoferrin mRNA quantitation, we will likely utilize Taq Man quantitation given the ease of analysis and the more sensitive quantitative nature of this new technique.

Task/Specific Aim \#2. Characterize the putative 4-hydroxyestradiol receptor in ER- $\alpha$ minus mice. Subcellular fractionation and dose response for some ${ }^{3} \mathrm{H}-4$-hydroxyestradiol.

Progress:

1998 Ongoing. We are about to label up some ${ }^{3} \mathrm{H}-4$-hydroxyestradiol made from ${ }^{3} \mathrm{H}$-estradiol catalyzed by human 4-hydroxylase obtained from either Colin Jefcoate or GenTest, Inc (Woburn, Mass.). This will provide the reagents needed for these in vitro studies. 
Lubahn: ER-minus mice

1999 In progress. We are currently generating radiolabeled ${ }^{3} \mathrm{H}$-4-hydroxyestradiol from ${ }^{3} \mathrm{H}$ - $17 \beta$-estradiol catalyzed by human 4-hydroxylase obtained from GenTest Corp. (Woburn, MA). Briefly, ${ }^{3} \mathrm{H}$-estradiol is incubated at $37^{\circ} \mathrm{C}$ for 30 minutes with 4-hydroxylase microsomes and NADPH cofactor. The reaction is terminated with the addition of $\mathrm{MTBE}$, after which time the organic solvent extracts are combined and evaporated to dryness under nitrogen. The resulting residue is dissolved in $100 \%$ methanol ( $5 \mathrm{mM}$ ascorbic acid) and analyzed for metabolite composition by HPLC. Estrogen metabolites are separated on a $5 \mu$ LUNA C18 column (250 X $4.6 \mathrm{~mm}$ ) (Phenomenex; Torrence, CA) (See Figure ????????). All separations are performed at room temperature at a flow rate of $1 \mathrm{ml} / \mathrm{min}$ and the solvent system used for separation consists of $70 \%$ $\mathrm{MeOH} / 30 \% \mathrm{H} 2 \mathrm{O}$.

Preliminary data indicates generation of ${ }^{3} \mathrm{H}-4$-hydroxyestradiol, along with other radiolabeled estrogen metabolites. One of these metabolites is ${ }^{3} \mathrm{H}$-2-hydroxyestradiol, which is synthesized (although at smaller amounts) along with ${ }^{3} \mathrm{H}-4$-hydroxyestradiol, by human 4-hydroxylase. ${ }^{3} \mathrm{H}-2$-hydroxyestradiol may be used in ligand binding and competition studies for characterizing the putative 4-hydroxyestradiol ("ER $\gamma$ ") receptor. Once optimal enzyme conditions are obtained, ${ }^{3} \mathrm{H}-4$-hydroxyestradiol will be separated/purified by HPLC and utilized for ligand binding and competition experiments. Depending on the amount of specific ${ }^{3} \mathrm{H}-4$ hydroxyestradiol "bound" counts, ${ }^{125} \mathrm{I}-17 \beta$-estradiol may be used as substrate in order to achieve a significant level of detectable 4-hydroxyestradiol binding.

Task/Specific Aim \#3. Compare the specificity of the responses to 4-hydroxyestradiol with those of estradiol, 2-hydroxyestradiol, 4-methoxyestradiol, methoxychlor, and tamoxifen in ER- $\alpha$ minus mice. Differential display and candidate responses.

Progress:

1998 Ongoing. Early results by differential display PCR are promising for a specific mRNA response unique to 4-hydroxyestradiol but not inhibited by ICI or observed with estradiol, thus indicating the 4OHE2 response is not mediated by ER- $\alpha$ or ER- $\beta$. Based upon elevated uterine lactoferrin mRNA expression by 4-hydroxyestradiol in ovariectomized ER $\alpha$ KO female mice via a non-ER $\alpha$, non-ER $\beta$ mechanism (102), we employed differential display analysis to identify other estrogen-responsive genes uniquely regulated by 4-hydroxyestradiol in the uteri $\mathrm{ER} \alpha \mathrm{KO}$ female mice.

In this task, the differential display technique identified a putative down-regulated gene in response to 4hydroxyestradiol, but not to $17 \beta$-estradiol, in the uteri of ovariectomized ER $\alpha \mathrm{KO}$ mice. An estrogen receptor antagonist, ICI 182,780 , failed to inhibit this down-regulation induced by 4-hydroxyestradiol. Currently, the CDNA product is being further amplified and will subsequently be purified and sequenced. Differential display RT-PCR identified a potential gene product whose expression is down regulated by 4-hydroxyestradiol, but not by $17 \beta$-estradiol, in ER $\alpha$ KO mouse uterine tissue (See Figure 2 below). The failure of ICI 182,780 to antagonize gene down-regulation suggests a non-ER $\alpha$, non-ER $\beta$ mechanism for 4-hydroxyestradiol-induced uterine gene expression. The ability of 4-hydroxyestradiol to down-regulate gene expression independent of ER $\alpha /$ ER $\beta$ supports the hypothesis that catethol estrogens are biologically active compounds in their own right and not merely benign excretory products

1999 Ongoing. Early results by differential display RT-PCR identified a putative down-regulated gene in response to 4-hydroxyestradiol, but not to $17 \beta$-estradiol, in the uteri of ovariectomized ER $\alpha$ KO mice. The ER antagonist, ICI 182,780 , failed to inhibit this down-regulation induced by 4-hydroxyestradiol. Repeat RT-PCR and experimental treatment indicated this original candidate gene to be a false positive, a common occurrence for differential display RT-PCR. Given the problems with uterine RNA (see Task/Specific Aim \#1), we are currently examining liver tissue for 4-hydroxyestradiol-induced candidate response genes. Integrity and reproducibility among liver RNA samples have been nearly infallible, thus providing us with a more reproducible tissue source with which to identify specific 4-hydroxyestradiol-regulated genes.

Considering the limitations with differential display RT-PCR, microarray technology would allow us to simultaneously analyze thousands of genes at once, some of which we believe are uniquely regulated by 4hydroxyestradiol via "ER $\gamma$ ". Identification of the genes specifically regulated by ER $\beta$ and ER $\gamma$ are necessary in 
order to determine their functions. A microarray initiative to aid in determining these functions would be immensely helpful. Our own efforts to explore this microarray approach have quickly run into the obvious problem of cost. Microarray technology is still an expensive approach but it is obviously the technique of choice for gene expression analysis. We hope to utilize microarray technology in the very near future as costs become more affordable, but will continue with differential display analysis until such time. 

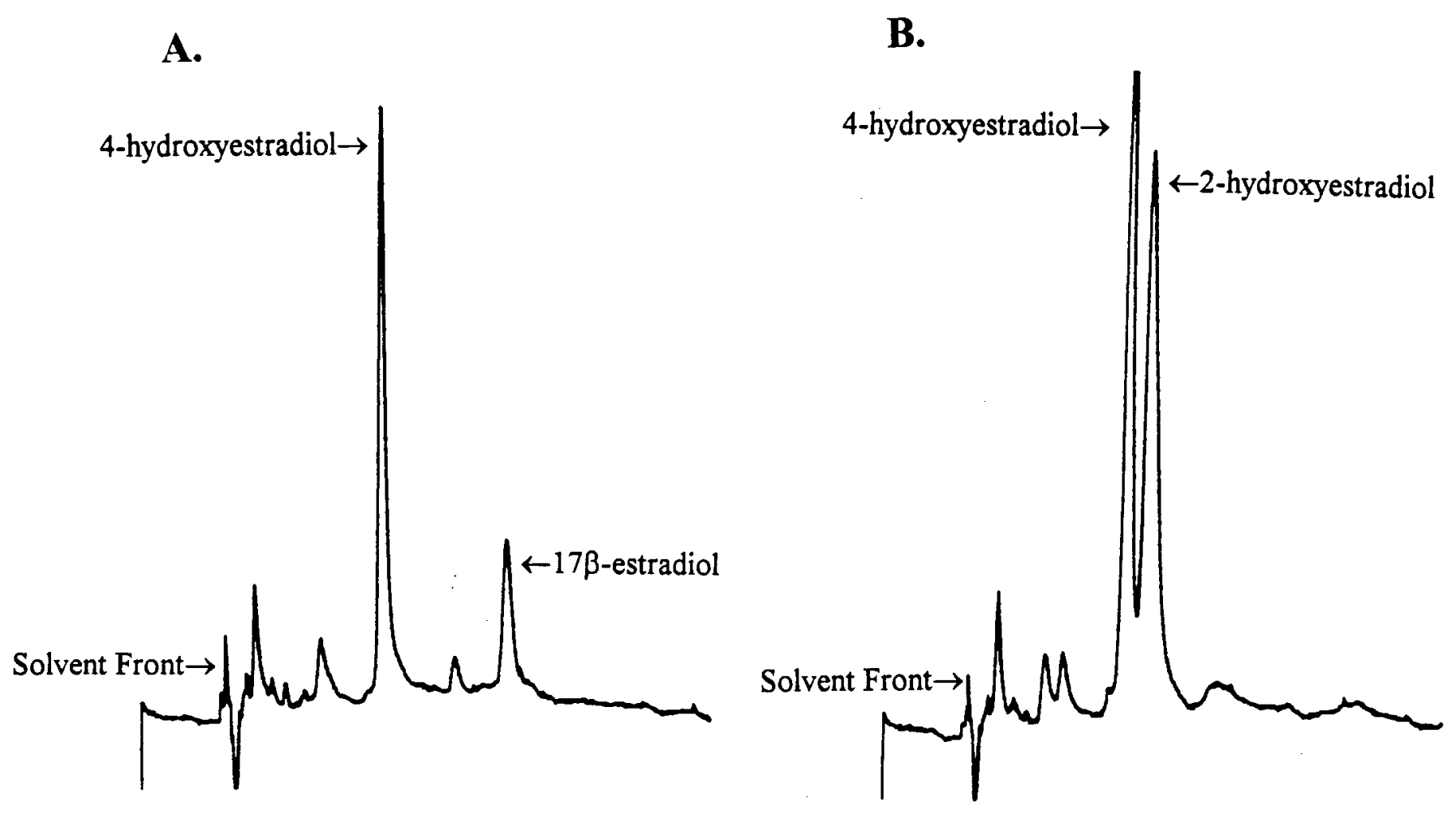

Figure 2. HPLC of $17 \beta$-estradiol and related catechol estrogens. The HPLC profiles of (A) 17ß-estradiol + 4-hydroxyestradiol and (B) 2-hydroxyestradiol + 4-hydroxyestradiol were determined using a LUNA reverse-phase $C_{18}$ column with an isocratic mobile gradient system of methanol-water (70:30). Flow rate was $1 \mathrm{ml} / \mathrm{min}$ and absorbance at $260 \mathrm{~nm}$ was monitored with a sensitivity of 0.02 absorbance units as full scale. Retention times were as follows: $10.2 \mathrm{~min}$ for $17 \beta$-estradiol, $6.7 \mathrm{~min}$ for 4 -hydroxyestradiol, and $7.3 \mathrm{~min}$ for 2-hydroxyestradiol. Smaller peaks represent minor impurities. HPLC profiles demonstrate that we are able to easily separate parent compound (17 $\beta$-estradiol) from product compounds (2-, 4-hydroxyestradiol). 
Task/Specific Aim \#4. Clone the putative 4-hydroxyestradiol receptor (4OHER).

4a. Test for 4-hydroxyestradiol binding and responses through Gustaffson's ER-beta. 4b. Screen for receptors that change concentration by differential display PCR analysis in the steroid receptor families using anchored oligonucleotide primers.

4c. Screen uterine ER- $\alpha$ minus mouse cDNA library with probes from conserved sequences of the steroid receptor super family via low stringency hybridization.

4d. Test expressed candidate orphan receptor cDNAs for binding to 4-hydroxyestradiol.

4e. Expression cloning using $\left[{ }^{3} \mathrm{H}\right]$ - 4-hydroxyestradiol.

4f. Purification by affinity chromatography, then obtain partial peptide sequence for raising epitope specific antibodies or synthesizing oligonucleotide probes for screening of ER- $\alpha$ minus cDNA libraries.

4g. After full-length cDNA clone isolation and sequencing from one of the approaches above (a-f) we will confirm or verify identity of putative receptor by:

i. in vitro expression and binding to labeled 4-hydroxyestradiol, or

ii. testing for transcriptional activation of a lactoferrin promoter reporter construct

(or other 4-hydroxyestradiol-responsive promoter) with the receptor bound to 4-hydroxyestradiol.

4h. Tissue specific localization of 4-hydroxyestradiol receptor mRNA expression will be ascertained by

RT-PCR, Northern blot analysis, or in situ hybridization.

\section{Progress:}

1998 Ongoing.

4a. 4-hydroxy estradiol has been shown in a paper by Gustafsson in March 1997 Endocrinology to bind to both ER- $\alpha$ and ER- $\beta$. However, this is not the mechanism of the 4-hydroxy estradiol response we have been observing because ER- $\beta$ is blocked/binds by ICI and estradiol. We are currently testing a new hypothesis that an alternatively spliced form of ER- $\alpha$ or ER- $\beta$ and/or a heterodimerization of the two may provide unique specificity for 4-hydroxy estradiol.

$4 \mathrm{~b}-4 \mathrm{f}$. Ongoing but very early stages. No results yet.

1999 Ongoing.

4a. These studies continue. In preliminary data stably transfected ERa and Erb in ER negative MCF-7 cell lines have shown no detectable estrogen binding in the ER-beta lines but do show binding in the ER-a stably transfected lines. Interestingly, when these two types of cell lines are transfected with a construct containing an ERE promoter driving a luciferase reporter and exposed to estradiol, the ER-b line activates the reporter better than the ERa line. Western analyses are ongoing to confirm the quantities of the stably transfected ER-beta. If confirmed, this is the first time that anyone has shown in any cell line that there is a lack of correlation between binding and transcription activation, which may lead to a better understanding of factors that alter the ligand binding specificity, affinity and kinetics of ER. We are also isolating the recently found ERR3 to see if it will bind to catechol estrogens and have isolated various ER-beta alternatively spliced forms and will check their responses to catechol estrogens.

$4 \mathrm{~b}-4 \mathrm{f}$ Ongoing. Many of these are contingent on obtaining labeled catechol estrogens. We are once again redesigning new primers designed from the host of new fish ERs that have been reported. Recent reports are very encouraging. For example, there are now 3 ERs in goldfish. These primers will be used to amplify mammalian DNAs and cDNAs in hopes of finding a third mammalian estrogen receptor. The original attempt at this with just a few fish ERs was unsuccessful. 


\section{Reportable Outcomes:}

1) A copy of a paper was attached last year as an appendix. (Reference 102. Estrogenic responses in estrogen receptor-alpha deficient mice reveal a novel estrogen signaling pathway. Das SK. Taylor JA. Korach KS. Paria BC. Dey SK. Lubahn DB. Proceedings of the National Academy of Sciences USA 94: 12786-12791, 1997.)

2) A new Endocrinology paper is attached. Ghosh et al. 1999 (Reference 103) See Appendix where it is attached. 


\section{Conclusions:}

Endogenous estrogens can be hydroxylated at multiple sites by NADPH-dependent cytochrome P450 enzymes. The catechol estrogens, 2- and 4-hydroxyestradiol, are a major group of estrogen metabolites formed by the aromatic hydroxylation of $17 \beta$-estradiol at the $\mathrm{C}-2$ and $\mathrm{C}-4$ positions, respectively. In mammalian species, catechol estrogen formation from $17 \beta$-estradiol is quantitatively the most important metabolic pathway of this endogenous sex hormone. Among the different metabolites of $17 \beta$-estradiol, only 2 - and 4-hydroxyestradiol have been found to bind to both $\mathrm{ER} \alpha$ and $\mathrm{ER} \beta$ with a relatively high affinity. Although previously believed to be to be benign excretory products, recent evidence suggests that catechol estrogens may be local mediators of estrogen action that possess potent biological and endocrine activities of their own (102,103). In MCF-7 cells, 2- and 4hydroxyestradiol have been shown to significantly stimulate cell growth and increase progesterone receptor. Effects on embryo implantation, gonadotropin release, partruition and increases in uterine weight also have been reported. More importantly, catechol estrogens have been implicated in hormone-induced carcinogenesis as reviewed earlier (74-101).

To better understand the receptor mechanisms mediating the multitude of estrogenic effects, Lubahn et al. (1) generated $\mathrm{ER} \alpha$ "knock-out" $(\mathrm{ER} \alpha \mathrm{KO})$ mice using homologous recombination techniques. In these transgenic mice, uterine mRNA expression of the estrogen-responsive gene lactoferrin has been shown to be upregulated by the catechol estrogen 4-hydroxyestradiol and methoxychlor, but not by $17 \beta$-estradiol $(102,103)$. These results suggest the presence of a novel non-ER $\alpha$, non-ER $\beta$ estrogen signaling pathway.

Our new working hypothesis is that the methoxychlor receptor (103) is also the catechol estrogen receptor. This is based primarily on the similar structure of the ligands (See Figure 1) and the capacity of methoxychlor to be metabolized to a catechol form like the catechol estrogen receptor (20). 


\section{References}

1. Lubahn DB, et al. 1993 Alteration of reproductive function but not prenatal sexual development after insertional disruption of the mouse estrogen receptor gene. PNAS USA 90:11162-11166

2. Couse JF, et al. 1995 Analysis of Transcription and Estrogen Insensitivity in the Female Mouse After Targeted Disruption of the Estrogen Receptor Gene. Molecular Endocrinology 9:1441-1454.

3. Ball P and Knuppen R. 1980 Catecholoestrogens (2- and 4-hydroxyoestrogens): Chemistry, biogenesis, metabolism, occurrence and physiological significance. Acta Endocrino Logica (Supp. 232).

4. Fishman J. 1981 Biological action of catechol oestrogens. J. Endocr. 89:59-65.

5. Dey, SK and Johnson DC. 1986 Embryonic signals in pregnancy. Ann. NY Acad. Sci. 476:49-62.

6. Ball P, and Knuppen R. 1990 Formation, metabolism, and physiologic importance of catecholestrogens. Am J Obstet Gynecol 163:2163-2170.

7. Martucci CP \& Fishman J. 1993 P450 enzymes of estrogen metabolism Pharmac. Ther. 57:237-257.

8. Liehr JG, et al 1995. 4-hydroxylation of estradiol by human uterine myometrium and myoma microsomes: implications for the mechanism of uterine tumorigenesis. PNAS USA 92:9220-9224.

9. Weisz J, Bui QD, Roy D, Liehr JG 1992 Elevated 4-hydroxylation of estradiol by hamster kidney microsomes: a potential pathway of metabolic activation of estrogens. Endocrinology 131:655-661

10. Zhu BT, et al 1994 Conversion of estrone to 2- and 4-hydroxyestrone by hamster kidney and liver microsomes: implications for the mechanism of estrogen-induced carcinogenesis. Endo 135:1772-1779

11. Merriam GR, et al 1980 Rapid metabolic clearance of the catechol estrogen 2-hydroxyestrone. J Clinical Endocrinology and Metabolism 51:1211-1213.

12. Spink DC, et al 1994 The effects of dioxin on estrogen metabolism in MCF-7 breast cancer cells: Evidence for induction of a novel 17b-estradiol 4-hydroxylase. J Ster Bioch. Molec. Biol. 51:251-258.

13. Hersey RM, Weisz J and Katzenellenbogen BS 1982 Estrogenic potency, receptor interactions, and metabolism of catechol estrogens in the immature rate uterus in vitro. Endocrinology 111:896-903.

14. Van Aswegen CH, Purdy RH, Wittliff JL 1989 Binding of 2-hydroxyestradiol and 4-hydroxyestradiol to estrogen receptors from human breast cancers. Journal of Steroid Biochemistry 32:485-492.

15. Orchnik M, McEwen BS 1995 Rapid steroid actions in the brain: A critique of genomic \& nongenomic mechanisms. In: (M Wehling, ed) Genomic \&Non-Genomic Effects of Aldosterone, CRC Press, pp 77-108.

16. Duval D, Durant S, Homo-Delarche F 1983 Non-genomic effects of steroids: Interactions of steroid molecules with membrane structures and functions. Biochim Biophys Acta 737:409-442

17. Weiss DJ, Gurpide E 1988 Non-genomic effects of estrogens \& antiestrogens. J Steroid Biochem 31:671-6.

18. McEwen BS 1991 Non-genomic \& genomic effects of steroids on neural activity Trends in Pharm Sci $12: 141-7$

19. Schaeffer JM, Stevens S, Smith RG, Hsueh AJW 1980 Binding of 2-hydroxyestradiol to rat anterior pituitary cell membranes. J Biol Chem 255:9838-9843

20. Kupfer D, Bulger WH, and Theoharides AD. 1990 Metabolism of methoxychlor by hepatic P-450 monooxygenases in rat and human. I. Characterization of a novel catechol metabolite. Chem Res Tox 3:8-16

21. J-A Gustafsson Keystone-Lake Tahoe Meeting - March 1996

22. Kuiper GGJM, Enmark E, Pelto-Huikkio M, Nilsson S and Gustafsson J-A (June 1996)

23. Cloning of a novel estrogen receptor expressed in rat prostate and ovary. PNAS USA 93:5925-5930

24. Giguere V, et al. 1988 Identification of a new class of steroid hormone receptors. Nature 331:91-4

25. Aronica SM, Kraus WL, Katzenellenbogen BS 1994 Estrogen action via the cAMP signaling pathway: Stimulation of adenylate cyclase and cAMP-regulated gene transcription. PNAS USA 91:8517-8521

26. Pietras RJ, Szego CM 1980 Partial purification and characterization of oestrogen receptors in subfractions of hepatocyte plasma membranes. Biochem J 191:743-760

27. Towle AC, Sze PY 1983 Steroid binding to synaptic plasma membrane: Differential binding of glucocorticoids and gonadal steroids. J Steroid Biochem 18:135-143 
Lubahn: ER-minus mice

28. Bression D, Michard M, LeDafniet M, Pagesy P, Peillon F 1986 Evidence for a specific estradiol binding site on rat pituitary membranes. Endocrin. 119:1048-1051

29. Pappas TC, Gametchu B, Yannariello-Brown J, Collin TJ, Watson CS 1994 Membrane estrogen receptors in $\mathrm{GH} 3 / \mathrm{B} 6$ cells are associated with rapid estrogen-induced release of prolactin. Endo. 2:813-822

30. Berthois Y, et al. 1986 Estradiol membrane binding sites on human breast cancer cell lines. Use of a fluorescent estradiol conjugate to demonstrate plasma membrane binding. J Steroid Biochem 25:963-72

31. Nenci I, et al. 1980 Cytochemical evidence for steroid binding sites in the plasma membrane of target cells In: (Bresciani F, ed) Perspectives in Steroid Receptor Research, Raven Press, New York, pp 61-72

32. Pietras RJ, Szego CM 1977 Specific binding sites for oestrogen at the outer surfaces of isolate endometrial cells. Nature 265:69-72

33. Gray WG, et al. 1994 A low affinity estrogen-binding site in pregnant rat uteri. PNAS USA 91:11502

34. Markaverich BM, Gregory RR 1991 Preliminary characterization and partial purification of rat uterine nuclear type II binding sites Biochem Biophys Res Comm 177:1283-90

35. Sudo K, Monsma Jr FJ, Katzenellenbogen BS 1983 Antiestrogen-binding sites distinct from the estrogen receptor: Subcellular localization, ligand specificity, and distribution in tissues of the rat. Endo 112:425-4

36. Sheen YY, Simpson DM, Katzenellenbogen BS 1985 An evaluation of the role of antiestrogen-binding sites in mediating the growth modulatory effects of antiestrogens. Endocrinology 117:561-564

37. Pavlik EJ, et al. 1992 Resistance to tamoxifen with persisting sensitivity to estrogen: Possible mediation by excessive antiestrogen binding site activity. Cancer Research 52:4106-4112

38. Welshons WV, Grady LH, Judy BM, Jordan VC, Preziosi 1993 Subcellular compartmentalization of MCF-7 estrogen receptor synthesis and degradation. Mol Cell Endo.. 94:183-194

39. Matsuda S, Kadowaki Y, Ichino M, Akiyama T, Toyoshima, Yamamoto T 1993 17ß-estradiol mimics ligand activity of the c-erbB2 protooncogene product. Proc Natl Acad Sci USA 90:10803-10807

40. Shupnik MA, Gordon MS, Chin WW 1989 Tissue-specific regulation of rat estrogen receptor mRNAs. Molec Endocrin 3:660-665

41. Friend KE, Ang LW. and Shupnik MA. 1995 Estrogen regulates the expression of several different estrogen receptor mRNA isoforms in rat pituitary. Proc. Natl. Acad. Sci. USA. 92:4367-4371.

42. vom Saal FS, Welshons WV, et al. 1995 Estrogenic pesticides: binding relative to estradiol in MCF-7 cells and effects of exposure during fetal life on subsequent territorial behavior in male mice. Tox. Let. 77:343-50

43. Bitman J and Cecil H 1970 Estrogenic activity of the insecticide chlordecone (kepone) and interaction with uterine estrogen receptors. J. Agr. Food Chem. 8: 1108-1120.

44. ATSDR 1994 Toxicological Profile for Methoxychlor. U.S. Dept. of Health \& Hum. Services.

45. Hammond B, Katzenellenbogen BS, Krauthammer N \& McConnell J 1979 Estrogenic activity of the insecticide chlordecone (kepone) and interaction with uterine estrogen receptors. PNAS 76:6641-45

46. Wakeling AE, Dukes M and Bowler J. 1991 A potent specific pure antiestrogen with clinical potential. Cancer Research 51:3867-3873.

47. Parisot JP, Hu XF, Sutherland RL, Wakeling A, Zalcberg JR \& DeLuise M. 1995 The pure antiestrogen ICI 182,780 binds to a high-affinity site distinct from the estrogen receptor. Int. J. Cancer. 62:480-484.

48. Lloyd T, et al. 1982 A comparison of 2-hydroxyestradiol \& U-0521 (3',4'-dihydroxy-2-methylpropiophenone, Upjohn) as in situ \& in vitro inhibitors of tyrosine hydroxylase. J Neurochem 38:948-54.

49. Yu LC, Chen YH 1993 The developmental profile of lactoferrin in mouse. Biochem J 296:107-111.

50. Walmer DK, et al. 1992 Lactoferrin espression in the mouse reproductive tract during the natural estrous cycle: Correlation with circulating estradiol and progesterone.Endocrinology 131:1458-66.

51. Teng CT, Pentecost BT, Chen YH, Newbold RR, Eddy EM, McLachlan JA. 1989 Lactotransferrin gene expresson in the mouse uterus and mammary gland. Endocrinology 124:992-999.

52. Surveyor GA, et al. 1994 Expression and steroid hormonal control of muc-1 in the mouse uterus. Endocrinology 136:3639-3647.

53. Lubahn DB, et al. 1988 Cloning of Human Androgen Receptor Complementary DNA and Localization of the Gene to Centromere-q13 on the X Chromosome Science 240:327-330. 
54. Lubahn DB, McCarty KS, Sr. \& McCarty KS, Jr 1985 Electrophoretic Characterization of Purified Bovine, Porcine, Murine, Rat and Human Estrogen Receptors. J. Biol Chemistry 260:2515-2526.

55. Lubahn DB, et al. 1988 Human Androgen Receptor: Complementary DNA Cloning, Sequence Analysis and Gene Expression in Prostate. Molecular Endocrinology 2:1265-1275.

56. Ji I, Ji H, Ji TH 1993 Direct autoradiography after radio-ligand binding to identify mammalian cell clones expressing hormone receptor cDNA. Nucleic Acids Research 21, 4420-4421

57. Matthew LS and Vale WW. 1991 Expression cloning of an activin receptor, a predicted transmembrane serine kinase. Cell 65:973-982.

58. Gearing DP, King JA, Gough NM and Nicola NA. 1989 Expression cloning of a receptor for human granulocyte-macrophage colony-stimulating factor. The EMBO Journal 8:3667-3676.

59. Wang XN, et al. 1994 Differential regulation of heparin-binding epidermal growth factor-like growth factor in the adult ovariectomized mouse uterus by progesterone and estrogen. Endo.135:1264-71.

60. Das SK, et al. 1994 Heparin-binding EGF-like growth factor gene is induced in the mouse uterus temporally by the blastocyst Development 120:1071-83.

61. Golding T A and Korach KS 1988 Nuclear estrogen receptor molecular heterogeneity in the mouse uterus. Proc. Natl. Acad. Sci. USA 85:69-73.

62. Labarca D, and Paigen K 1980 A simple, rapid, and sensitive DNA assay procedure.. Anal Biochem., 102:344-352.

63. Welshons WV, Grady LH, Judy BM, Jordan VC \& Preziosi 1993 Subcellular compartmentalization of MCF7 estrogen receptor synthesis and degradation. Mol Cell Endo 94:183-94.

64. Bradford M. 1976 A rapid and sensitive method for the quantitation of microgram quantities of protein utilizing the principle of protein dye binding. Anal. Biochem. 72:248-254.

65. Liang, P. and Pardee, A.B. 1992 Differential display of eukaryotic messenger RNA by means of the polymerase chain reaction. Science 257: 967-971

66. Chapman MS, et al. 1995 Isolation of differentially expressed sequence tags from steroid-responsive cells using mRNA differential display. Molecular and Cellular Endocrinology 108:R1-R7.

67. Trentmann SM, vander Knaap E, Kende H. 1995 Alternatives to ${ }^{35} \mathrm{~S}$ as a label for the differential display of eukaryotic messenger RNA. Science 267:1186-1187.

68. Lubahn DB (1992-1994) Orphan receptor data (unpublished). Obtained while at Glaxo Res. Institute.

69. Sambrook J, Fritsch EF, Maniatis T. eds (1989) Molecular Cloning - A laboratory manual, 2nd Edition. Cold Spring Harbor Laboratory Press.

70. Ausubel FM, Brent R, Kingston RE, Moore DD, Seidman JG, Smith JA, Struhl K eds. (1989) Current Protocols in Molecular Biology. Greene Publishing Associates and Wiley- Interscience, New York, NY.

71. Pentecost BT, Teng CT 1987 Lactotransferrin is the major estrogen inducible protein of mouse uterine secretions. J Biol Chem 262:10134-9.

72. Paria BC, Das SK, Andrews GK, Dey SK, 1993 Expression of the epidermal growth factor receptor gene is regulated in mouse blastocysts during delayed implantation. Proc.Nat. Acad. Sci. USA 90:55-9.

73. Imai T, et al. 1995 Changes in epidermal growth factor receptor and the levels of its ligands during menstrual cycle in human endometrium. Biology of Reproduction. 52:928-38.

74. Liehr JG, Ricci MJ. (1996) 4-Hydroxylation of estrogens as marker of human mammary tumors. Proceedings of the National Academy of Sciences of the USA. 93:3294-3296.

75. Yager JD, Liehr JG. (1996) Molecular mechanisms of estrogen carcinogenesis [Review]. Annual Review of Pharmacology \& Tox 36:203-232.

76. Dehal SS, Kupfer D. (1996) Evidence that the catechol 3, 4-dihydroxytamoxifen is a proximate intermediate to the reactive species binding covalently to proteins. Cancer Res 56:1283-1290.

77. Bradlow HL, Davis DL, Lin G, Sepkovic D, Tiwari R (1995). Effects of pesticides on the ratio of 16 $\alpha / 2-$ hydroxyestrone: a biologic marker of breast cancer risk. Environmental Health Perspectives 103 Suppl 7:147150.

78. Wittliff JL, Raffelsberger W. (1995) Mechanisms of signal transduction - sex hormones, their receptors and clinical utility [Review]. J Clinical Ligand Assay 18:211-235. 
79. Nutter LM, Wu YY, Ngo EO, Sierra EE, Gutierrez PL, Abul-Hajj YJ. (1994) An o-quinone form of estrogen produces free radicals in human breast cancer cells: correlation with DNA damage. Chem Res in Tox 7:23-28.

80. Schutze N, Vollmer G, Wunsche W, Grote A, Feit B, Knuppen R. (1994) Binding of 2-hydroxyestradiol and 4-hydroxyestradiol to the estrogen receptor of MCF-7 cells in cytosolic extracts and in nuclei of intact cells. Experimental \& Clinical Endocrinol. 102:399-408.

81. Schutze N, Vollmer G, Tiemann I, Geiger M, Knuppen R (1993) Catecholestrogens are MCF-7 cell estrogen receptor agonists. J. Steroid Biochem. \& Molecular Biol. 46:781-789.

82. Lemon HM, Heidel JW, Rodrigguez-Sierra JF. (1992) Increased catechol estrogen metabolism as a risk factor for non familial breast cancer. Cancer. 69:457-465.

83. Lottering ML, Haag M, Seegers JC. (1992) Effects of $17 \beta$-estradiol metabolites on cell cycle events in MCF7 cells. Cancer Res. 52:5926-5932.

84. Telang NT, Suto A, Wong GY, Osborne MP, Bradlow HL. (1992) Induction by estrogen metabolite $16 \alpha-$ hydroxyestrone of genotoxic damage and aberrant proliferation in mouse mammary epithelial cells. J National Cancer Institute. 84:634-638.

85. Swaneck GE, Fishman J (1991) Effects of estrogens on MCF-7 cells: positive or negative regulation by the nature of the ligand-receptor comples. Biochem. \& Biophys. Res. Communications 174:276-281.

86. Arts CJ, Wilmer JW, deBie AT, van den Berg H. (1990) In vitro synthesis of $16 \alpha$-hydroxyestrone by female rat liver microsomes: its possible role in the etiology of breast cancer. J Steroid Biochem. 36:527-531.

87. Thijssen JH, Blankenstein MA. (1990) Uptake and metabolism of estradiol by normal and abnormal breast tissues. Annals of the New York Academy of Sci. 586:252-258.

88. Van Aswegen CH, Purdy RH, Wittliff JL. (1989) Binding of 2-hydroxyestradiol and 4-hydroxyestradiol to estrogen receptors from human breast cancers. J of Steroid Biochem. 32:485-492.

89. Vandewalle B, Lefebvre J (1989) Opposite effects of estrogen and catecholestrogen on hormone-sensitive breast cancer cell growth and differentiation. Molecular \& Cellular Endocrinology 61:239-246.

90. Swaneck GE, Fishman J. (1988) Covalent binding of the endogenous estrogen 16 $\alpha$-hydroxyestrone to estradiol receptor in human breast cancer cells: characterization and intranuclear localization. Proceedings of the National Academy of Sciences of the USA 85:7831-7835.

91. Vandewalle B, Hornez L, Lefebvre J. (1988) Characterization of catecholestrogen membrane binding sites in estrogen receptor positive and negative human breast cancer cell-lines. J. of Receptor Res. 8:699-712.

92. Levin M, Weisz J, Bui QD, Santen RJ. (1987) Peroxidatic catecholestrogen production by human breast cancer tissue in vitro. J of Steroid Biochem. 28:513-520.

93. Tanaka T. Katoh M, Kubodera A. (1986) The characteristic binding of catechol estrogens to estrogen receptors in 7, 12-dimethylbenz(a)anthracene-induced rat mammary tumors. Steroids 48:361-368.

94. Foster AB, Jarman M, Leung OT, McCague R, Leclercq G, Devleeschouwer N. (1985) Hydroxy derivatives of tamoxifen. J Med Chem 28:1491-1497.

95. Vandewalle B, Peyrat JP, Bonneterre J, Lefebvre J. (1985) Catecholestrogen binding sites in breast cancer. J of Steroid Biochem. 23:603-610.

96. Schneider J, Huh MM, Bradlow HL, Fishman J. (1984) Antiestrogen action of 2-hydroxyestrone on MCF-7 human breast cancer cells. J. of Biol. Chem. 259:4840-4845.

97. Schneider MR, Schonenberger H, Michel RT, Fortmeyer HP. (1982) Synthesis and evaluation of catechol analogs of diethylstilbestrol on a hormone-dependent human mammary carcinoma implanted in nude mice. $\mathrm{J}$. of Cancer Res \& Clin Oncology 104:219-227.

98. Abul-Hajj YJ. (1980) Binding of catechol estrogens to the estrogen receptor of dimethylbenz(A) anthracene induced rat mammary tumors. J. of Steroid Biochem. 13:83-88.

99. Abul-Hajj YJ. (1979) Effect of catechol estrogens on rat mammary tumors. Cancer Res. 39:4882-4886.

100. Hoffman AR, Paul SM, Axelrod J. (1979) Catecholestrogen synthesis and metabolism by human breast tumors in vitro. Cancer Res 39:4584-4587.

101. Assicot M, Contesso G, Bohuon C. (1977) Catechol-O-methyltransferase in human breast cancers. European J of Cancer 13:961-966. 
102. Estrogenic responses in estrogen receptor-alpha deficient mice reveal a novel estrogen signaling pathway. Das SK. Taylor JA. Korach KS. Paria BC. Dey SK. Lubahn DB. Proceedings of the National Academy of Sciences USA 94: 12786-12791, 1997.

103. Methoxychlor stimulates estrogen-responsive mRNAs in mouse uterus through a non-ER-alpha and nonER-beta mechanism. Ghosh D. Taylor JA Green JA Lubahn DB. Endocrinology 140:3526-3533, 1999. 


\section{Appendix}

See attached paper resulting from the funding of this work.

Ghosh D. Taylor JA Green JA Lubahn DB. Methoxychlor stimulates estrogen-responsive mRNAs in mouse uterus through a non-ER-alpha and non-ER-beta mechanism. Endocrinology 140:3526-3533, 1999. 


\title{
Methoxychlor Stimulates Estrogen-Responsive Messenger Ribonucleic Acids in Mouse Uterus through a Non-Estrogen Receptor (Non-ER) $\alpha$ and Non-ER $\beta$ Mechanism*
}

\author{
DEBJANI GHOSH, JULIA A. TAYLOR, JONATHAN A. GREEN, AND \\ DENNIS B. LUBAHN
}

Departments of Biochemistry and Child Health (D.G., J.A.T., D.B.L.) and Animal Sciences (J.A.G., D.B.L.), University of Missouri, Columbia, Missouri 65211

\begin{abstract}
ABSTrRaCT
This study examined the effects of the xenoestrogen methoxychlor ( $\mathrm{Mxc}$ ) on messenger RNA (mRNA) concentrations of two estrogenresponsive uterine genes, lactoferrin (LF) and glucose-6-phosphate dehydrogenase (G6PD). Ovariectomized wild-type (WT) and estrogen receptor $(\mathrm{ER}) \alpha$-knockout $(\mathrm{ER} \alpha \mathrm{KO})$ mice were treated with $\mathrm{Mxc}$ or estradiol-17 $\beta\left(\mathrm{E}_{2}\right)$ to determine whether $\mathrm{Mxc}$ acts via pathways that involve $\mathrm{ER} \alpha$. In WT mice, both $\mathrm{E}_{2}$ and Mxc stimulated increases in uterine LF and G6PD mRNA concentrations in a dose-dependent manner. Competitive pretreatment with the pure antiestrogen ICI 182,780 dramatically reduced $\mathrm{E}_{2}$-stimulated increases in mRNA concentrations but had no effect on Mxc-induced effects. Competitive
\end{abstract}

pretreatment with $\mathrm{E}_{2}$ had only a partially inhibitory effect on Mxcinduced responses. In the $\mathrm{ER} \alpha \mathrm{KO}$ mouse, $\mathrm{E}_{2}$ had little effect on uterine LF or G6PD mRNA concentrations, whereas Mxc stimulated marked increases in both LF and G6PD mRNAs. The Mxc-induced increases in LF and G6PD mRNAs in the $\mathrm{ER} \alpha \mathrm{KO}$ mouse were not suppressed by competitive pretreatment with either $\mathbf{E}_{2}$ or ICI 182,780 . Fold increases in mRNA concentrations for both genes induced by Mxc were similar for WT and ER $\alpha \mathrm{KO}$ mice. The results surprisingly indicate that a xenoestrogen, Mxc, can increase LF and G6PD mRNA concentrations by a mechanism that is not mediated through $\mathrm{ER} \alpha$ or $\mathrm{ER} \beta$, and acts through another pathway. (Endocrinology 140: 3526-3533, 1999)
$\mathrm{M}$ ETHOXYCHLOR $(\mathrm{Mxc})$ is a pesticide in current use that was developed as a replacement for dichlorodiphenyltrichloroethane (DDT). Data from several studies in rats indicate that Mxc behaves like a typical estrogen, comparable with estradiol-17 $\beta\left(\mathrm{E}_{2}\right)$. Mxc stimulates uterine growth and hypertrophy $(1,2)$ and increases uterine peroxidase (3) and ornithine decarboxylase activities (4). Mxc can also accelerate vaginal opening and induce persistent vaginal cornification (5), as well as increased uterine estrogen receptor (ER) expression $(6,7)$. However, in spite of the evidence for estrogenic activity, it is not yet known how, or through which ER, Mxc exerts its effects.

Mxc was long believed to act through the classic ER (ER $\alpha)$ protein, a ligand-activated transcription factor and a member of a large family of evolutionarily conserved nuclear hormone receptors. However, the discovery of an additional ER, $\operatorname{ER} \beta(8,9)$, has made it necessary to reevaluate estrogen action. Although the functional importance of ER $\beta v$ s. ER $\alpha$ is not yet established, the tissue-specific distribution of these two receptor forms (10) may imply tissue-specific agonistic or antagonistic actions of estrogens. For example, it has been shown that Mxc itself acts as an estrogen agonist at the level

Received October 21, 1998.

Address all correspondence and requests for reprints to: Dr. Dennis B. Lubahn, Departments of Biochemistry and Child Health, 163A Animal Science Research Center, 920 East Campus Drive, University of Missouri, Columbia, Missouri 65211. E-mail: lubahnd@missouri.edu.

* This work was supported by grants from the Environmental Protection Agency (R825295010), the National Institutes of Health (ES08272), and the U.S. Army (DAMD 17-97-1-7171). of uterus and oviduct but as an antagonist in the ovary (11). Although it has been shown that Mxc binds to both ER $\alpha$ and $\mathrm{ER} \beta(10,12)$, it is not yet known through which receptor Mxc or its estrogenic metabolite(s) acts. Mxc is converted in vivo by the liver to 2,2-bis(p-hydroxyphenyl)-1,1,1,-trichloroethane (HPTE). HPTE is thought to be the principal active metabolite of Mxc because it has a higher affinity for ER $\alpha$ than Mxc (13) and shows potent in vitro estrogenic activity (4).

The widespread presence in the environment of chemicals with the capacity to disrupt the functioning of the endocrine system has been extensively studied. These chemicals include pesticides and herbicides such as Mxc, DDT, chlorodecone (kepone), the polychlorinated biphenyls, and phenolic compounds; and they may act via many different mechanisms. One category of endocrine-disrupting chemicals are those that are able to bind to ERs (14) and have effects similar to those of endogenous estrogens. DDT, for example, now banned in the United States for pesticide use, has been shown to advance vaginal opening and increase ovarian and uterine weights in rats $(15,16)$. Kepone, another pesticide, also induces precocious vaginal opening in immature rats (17), and polychlorinated biphenyls too have been shown to induce precocious puberty and uterine growth in rats $(18$, 19). These chemicals can act in vivo via multiple mechanisms [for example, o, p'DDT, a structural analog of Mxc, binds to ERs, whereas p, p'DDE binds to androgen receptors (20)]. Though the action mechanisms of these estrogenic chemicals are not clear, these compounds have received a great deal of attention, in the past decade, as a possible cause of certain cancers and impaired reproduction in animals (21-23). 
Kuiper et al. $(10,12)$ have shown that some natural estrogens, including various xenobiotics and the estradiol metabolite 4-hydroxy estradiol (a catecholestrogen) may act through binding to both $\mathrm{ER} \alpha$ and $\mathrm{ER} \beta$. Using the $\mathrm{ER} \alpha$ knockout $(\mathrm{ER} \alpha \mathrm{KO})$ mice, which show negligible or no classical responses to $E_{2}(24)$, Das et al. $(25,26)$ have shown that 4-hydroxy estradiol and the xenoestrogen kepone have estrogenic actions mediated via a non-ER $\alpha$ and non-ER $\beta$ pathway.

In this study, we set out to characterize the effects and actions of the widely-used estrogenic pesticide Mxc on the messenger RNA (mRNA) concentrations of estrogen-responsive genes in the mouse uterus. Lactoferrin (LF) and glucose6-phosphate dehydrogenase (G6PD) are two well-known estrogen-responsive genes $(27-30)$, and this study includes both dose-response and time-course effects of Mxc on these genes. To separate out effects that might be mediated via $\mathrm{ER} \alpha$, from those mediated by $\mathrm{ER} \beta$ and/or other receptors, we examined the effects of Mxc on estrogen-inducible increases in mRNA concentration in the ER $\alpha \mathrm{KO}$ mice and wild-type (WT) controls. Our results demonstrate that Mxc can induce increases in estrogen-sensitive mRNA concentrations in a manner similar to $\mathrm{E}_{2}$ but through a pathway that does not involve either the classical $\operatorname{ER} \alpha$ or the recently discovered ER $\beta$.

\section{Materials and Methods}

\section{Chemicals}

$E_{2}(1,3,5$ [10]-Estratriene-3, 17 $\beta$-diol) and Mxc (DMDT; 1,1,1,-Trichloro-2,2,-bis-[p-methoxyphenyl]ethane) were purchased from Sigma Chemical Co. (St. Louis, MO). ICI-182,780 (ICI) was purchased from Tocris (Bristol, UK).

\section{Animals and injection schedule}

Animals were maintained and treated in accordance with University of Missouri Animal Care and Use Committee guidelines. Adult WT $(+/+)$ or homozygous ER $\alpha \mathrm{KO}(-/-)$ sibling mice of the same mixed genetic background $(129 / \mathrm{C} 57 \mathrm{BL} / 6 \mathrm{~J})$ were ovariectomized and rested for 2 weeks before treatment. All treatments were given as two dorsal sc $0.1-\mathrm{ml}$ injections, $6 \mathrm{~h}$ apart, of olive oil (vehicle control; Sigma Chemical Co.), $\mathrm{E}_{2}(10$ or $100 \mu \mathrm{g} / \mathrm{kg}$ BW), ICl $(15 \mathrm{mg} / \mathrm{kg})$, or Mxc $(1.8,3.75,5.7$, $7.5,10.5,15,22,30,45$, and $60 \mathrm{mg} / \mathrm{kg} \mathrm{BW}$ ), and animals were killed $12 \mathrm{~h}$ after the final injection. In a separate group of mice, $\mathrm{Mxc}(15 \mathrm{mg} / \mathrm{kg})$ was injected sc together with $E_{2}$ at doses of 10 and $100 \mu \mathrm{g} / \mathrm{kg} \mathrm{BW}$, or with ICI at a dose of $15 \mathrm{mg} / \mathrm{kg} \mathrm{BW}$. In these animals, $E_{2}$ and ICI were injected $30 \mathrm{~min}$ before $\mathrm{Mxc}$ injection.

Time-course studies $(2,6,12,18$, and $24 \mathrm{~h}$ for Mxc; and 12,18 , and $24 \mathrm{~h}$ for estradiol) were carried with a single injection of Mxc $(15 \mathrm{mg} / \mathrm{kg})$ or estradiol $(10 \mu \mathrm{g} / \mathrm{kg})$. All compounds $(0.1 \mathrm{ml} / \mathrm{mouse})$ were injected dorsally sc in olive oil vehicle.

\section{Isolation of RNA}

Treated animals were euthanized, and the uterus was quickly collected and snap frozen in liquid nitrogen. Total RNA was isolated using Tri-Reagent (Sigma Chemical Co.). After isolation, total RNA concentration was measured in a spectrophotometer. Based on the optical density reading, all RNA samples were brought to a concentration of 1 $\mu \mathrm{g} / \mu \mathrm{l}$ and run out on a $1 \%$ agarose gel to confirm the uniformity of the $18 \mathrm{~S}$ and $28 \mathrm{~S}$ RNA bands. The integrity and quality of the purified RNA were also monitored by measurement of the A260/280 ratio. Only RNA samples exhibiting a $260 / 280$ ratio greater than 1.6 and showing integrity of RNA by electrophoresis were used in further experiments.

\section{Reverse transcriptase (RT)-PCR}

Complementary DNA (cDNA) was prepared for LF, G6PD, and RPL7, using specific antisense primers $(0.4 \mu \mathrm{M})$ in the presence of 0.25 $\mu \mathrm{l}$ of avian myeloblastosis virus (AMV-RT), 2.5 $\times$ AMV-RT buffer, 0.25 $\mathrm{mM} \mathrm{MgCl}_{2}$, and $1 \mathrm{~mm}$ deoxynucleotide triphosphates, in a total reaction $\mathrm{vol}$ of $20 \mu \mathrm{l}$. RPL7 was used as a housekeeping gene to further countercheck for uniform RNA loading and to monitor the efficiency of RT reaction. One microgram of RNA was used as template in each reaction. The RT reaction was carried out at $48 \mathrm{C}$ for $1 \mathrm{~h}$, and the AMV-RT was then inactivated at $93 \mathrm{C}$ for $3 \mathrm{~min}$ and brought to $14 \mathrm{C}$ for $10 \mathrm{~min}$. One microliter of sample cDNA template for each gene, including RPL7, was then amplified by PCR in separate sets of reactions. A negative control (reaction mix but no template) was run in each RT-PCR reaction, both in RT and PCR reactions, to monitor for nonspecific amplification.

For RT and PCR of mouse LF, the primers used were $5^{\prime}-\mathrm{AG}$ GAAAGCCCCCCTACAAAC-3' [nucleotide number (nt) 289-308, sense] and 5'-GGAACACAGCTCTTTGAGAAGAAC-3' (nt 564-541, antisense); GenBank accession no. D88510.

The primers used for mouse G6PD were 5 '-CTCCTGCAGATGTTGTGTCT-3' (nt 842-861, sense) and 5'-TCATTGGGCTGCATACGGA-3' (nt 1245-1227, antisense); GenBank accession no. Z11911.

The primers for mouse RPL7 were 5'-TCAATGGAGTAAGCCCAAAG-3' (nt 383-402, sense) and 5'-CAAGAGACCGAGCAATCAAG-3' (nt 628-609, antisense); GenBank accession no. M29016.

For each gene, PCR was done in the presence of specific sense and antisense primers $(0.4 \mu \mathrm{M}), 0.1 \mathrm{mM} \mathrm{MgCl}, 0.4 \mathrm{~mm}$ deoxynucleotide triphosphates, $0.25 \mu \mathrm{l}$ Fisher-Taq DNA polymerase (Fisher Scientific, St. Louis, MO), and $2 \times$ Fisher-Taq polymerase buffer in a total reaction vol of $50 \mu \mathrm{l}$. The thermal cycling condition for LF and RPL7 was 30 cycles at $94 \mathrm{C}$ for $30 \mathrm{sec}, 55 \mathrm{C}$ for $30 \mathrm{sec}, 68 \mathrm{C}$ for $50 \mathrm{sec}$, with a preincubation at $94 \mathrm{C}$ for $3 \mathrm{~min}$ and final incubation at $68 \mathrm{C}$ for $7 \mathrm{~min}$. For G6PD, the thermal cycling conditions were slightly different at 30 cycles at $94 \mathrm{C}$ for $30 \mathrm{sec}, 55 \mathrm{C}$ for $40 \mathrm{sec}$, and $68 \mathrm{C}$ for $1 \mathrm{~min}$. Pre- and postincubation temperatures were the same as above. Uniformity of RNA loading for each sample was confirmed by electrophoresis of the RPL7 CDNA, and then LF and G6PD cDNA samples were coamplified with six different concentrations of competitor, as described below.

\section{Competitive $R T-P C R$ of $L F$}

Competitive RT-PCR was the method chosen to quantify the changes of RNA message because of the very limited amount of RNA obtainable from $\mathrm{ER} \alpha \mathrm{KO}$ mouse uteri. It is essentially the same procedure as that employed by Das et al. (25). The competitor template contains the same primer template sequence as the mouse target cDNA. This competitor template was a gift from Drs. S. K. Das and S. K. Dey and was generated by introducing a nonspecific DNA fragment into a mouse target cDNA clone. A 185-bp blunt-ended fragment (SspI), obtained from a pGEM7Zf(+) vector, was inserted into the LF cDNA at the StuI site. This DNA template was used as the competitor for competitive PCR of LF cDNA templates derived from the RT of uterine RNAs. One tenth of the total RT product was coamplified with 10 -fold increasing amounts of the competitive template ( $1 \mathrm{fg}-100 \mathrm{pg}$ ) by PCR for 30 cycles, with the mixture of sense and antisense oligonucleotides. The final sizes of the competitor template and target cDNA were $460 \mathrm{bp}$ and $275 \mathrm{bp}$, respectively. The PCR amplification conditions were the same as for RT-PCR.

\section{Competitive RT-PCR of G6PD}

The competitor template contains the same primer-annealing site as mouse target cDNA. A PCR product (350 bp) of the G6PD cDNA, generated by using the mouse G6PD primers described above, was subcloned into the PGEM-T Easy Vector. A 200-bp foreign piece of blunt-ended (ClaI) DNA was inserted (blunt-end ligation) within this PCR product in the KpnI restriction site and was used as a competitor template for quantitative PCR. The amplification conditions were the same as for RT-PCR, and the final sizes of the competitor template and target cDNA were $550 \mathrm{bp}$ and $350 \mathrm{bp}$, respectively. For G6PD, one fifth of the RT product was coamplified with 10 -fold increasing amounts of the competitive template ( $1 \mathrm{fg}-100 \mathrm{pg}$ ) by PCR for 30 cycles with the mixture of sense and antisense oligonucleotides. One fifth of the RT product was used in PCR amplification of G6PD instead of the one tenth 
used for LF, because G6PD mRNA was expressed at lower levels than LF mRNA.

Amplified products were separated on $2 \%$ agarose (Agarose Low EEO, Fisher Scientific) gels and stained with ethidium bromide. Gels from different assays were scanned, and optical density units (peak area) for each sample and competitor were determined by using Gptools, version 3.0 (BioPhotonics Corp., Ann Arbor, MI). The ratio of band intensities of the competitor and target cDNA was calculated for each sample and plotted against the amounts of competitor. For each sample, a separate standard curve was prepared to determine the amount of mRNA for each specific gene. The amount of target cDNA was determined from the logarithm plot at the zero equivalence point, which represents $10 \%$ of the total (because only one tenth of the total reaction was used) for LF and $20 \%$ for G6PD total (because one fifth of the total reaction was used).

\section{Data analysis and statistics}

The concentration of mRNA for each gene was calculated as $\mathrm{fg} / \mu \mathrm{g}$ total RNA. Statistical analysis of the data was performed by ANOVA, followed by LSM $t$ test, using a SAS computer program (SAS system, version V-6.12, TS 020). Significance was accepted at $P<0.05$.

\section{Results}

To standardize the assay for measurement of LF and G6PD mRNAs stimulated by Mxc, we examined the effect of different cycle numbers and different starting RNA concentrations for each gene, under both untreated and treated (E2treated) conditions. These studies demonstrated the linearity and validity of the assay; and using these data (not shown), we selected a 30-cycle program and a starting concentration of $1 \mu \mathrm{g} \mathrm{mRNA}$ as optimal for use in further experiments.

After performing the RT reaction, each sample was amplified with its respective competitor template and quantified as described (details in Materials and Methods). Fig. 1A shows a representative diagram of coamplification of competitor and target cDNA for LF and G6PD genes in both WT and ER $\alpha \mathrm{KO}$ animals. Figure 1B shows an example of the logarithmic plots for control and induced samples (oil- and estradiol-treated WT animals) that are used to calculate mRNA concentrations.

\section{Time course of $L F$ and $G 6 P D m R N A$ responses to $E_{2}$}

A short time-course study was carried out with $\mathrm{E}_{2}(10 \mu \mathrm{g} / \mathrm{kg})$ as a positive control (Fig. $2 A$ ). For LF, a slow increase in mRNA concentrations starts from around 3 -fold at $12 \mathrm{~h}$, rising to about 6 -fold at $18 \mathrm{~h}$. The maximum (14-fold) response within the timeframe studied for LF was seen at $24 \mathrm{~h}$. In contrast, G6PD gave a peak response (17-fold) at $12 \mathrm{~h}$ and a decline in response (down to 4.8 -fold) at $18 \mathrm{~h}$. A further stimulation (6-fold) started at $24 \mathrm{~h}$, suggesting its stimulation to be bimodal.

\section{Time course of $L F$ and G6PD $m R N A$ responses to $M x c$}

Ovariectomized mice were injected with Mxc at $15 \mathrm{mg} / \mathrm{kg}$ BW, and tissues were collected at 2, 6, 12, 18, and $24 \mathrm{~h}$ after treatment. For LF mRNA, no response was seen until $12 \mathrm{~h}$ after treatment, when a 2 -fold increase was seen in both WT and $\mathrm{ER} \alpha \mathrm{KO}$ mice (Fig. 2B). A 7-fold increase was found at $18 \mathrm{~h}$, which was the time of maximum response for $\mathrm{LF}$ in this timeframe, followed by a slight decline (down to 5 -fold) at $24 \mathrm{~h}$. No differences in responses were observed between WT and ER $\alpha \mathrm{KO}$ mice in this time-course study.

For G6PD, no response was observed at $2 \mathrm{~h}$, either in WT
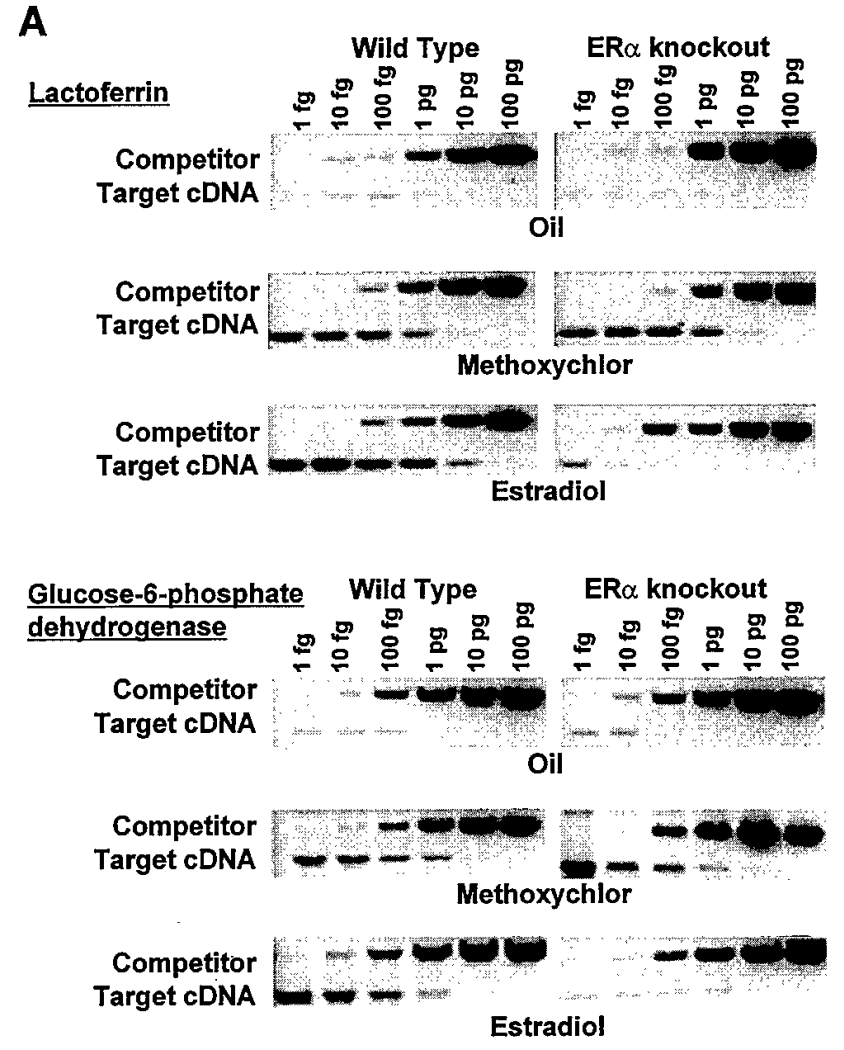

B

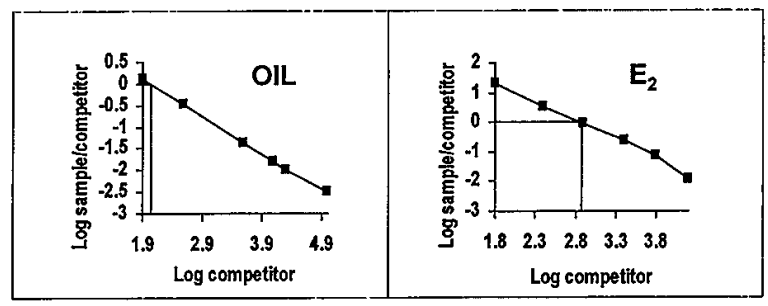

FIG. 1. A, Representative example of competitive PCR, where target cDNA was coamplified with its specific competitor. For both genes, six different concentrations of competitor ( $1 \mathrm{fg}-100 \mathrm{pg}$ ) were coamplified with each sample (control and treated) cDNA. B, Representative logarithmic plots of competitor vs. sample/competitor for control and $\mathrm{E}_{2}$-stimulated sample. The zero equivalence point was used to calculate the target cDNA concentration.

or ER $\alpha \mathrm{KO}$ mice (Fig. 2C). A slight increase (2-fold) was observed at $6 \mathrm{~h}$ in WT mice and also (3.8-fold) in ER $\alpha \mathrm{KO}$ animals. At 12 and $18 \mathrm{~h}$, WT mice did not show any further increase beyond that at $6 \mathrm{~h}$ (about 3-fold), but a 6-fold increase was found at $24 \mathrm{~h}$. However, $\mathrm{ER} \alpha \mathrm{KO}$ mice showed a further increase (to about 6-fold) at $12 \mathrm{~h}$ and $18 \mathrm{~h}$ and gave a peak response (9-fold) at $24 \mathrm{~h}$.

For further studies, $18 \mathrm{~h}$ was chosen for the end point, because this appeared optimal for both genes within the timeframe studied.

\section{Effects of different doses of Mxc on uterine $L F$ $m R N A$ concentrations}

Mxc $(3.75,5.7,7.5,10.5,15,22,30,45$, and $60 \mathrm{mg} / \mathrm{kg})$ induced increases in LF mRNA concentrations in a dose- 

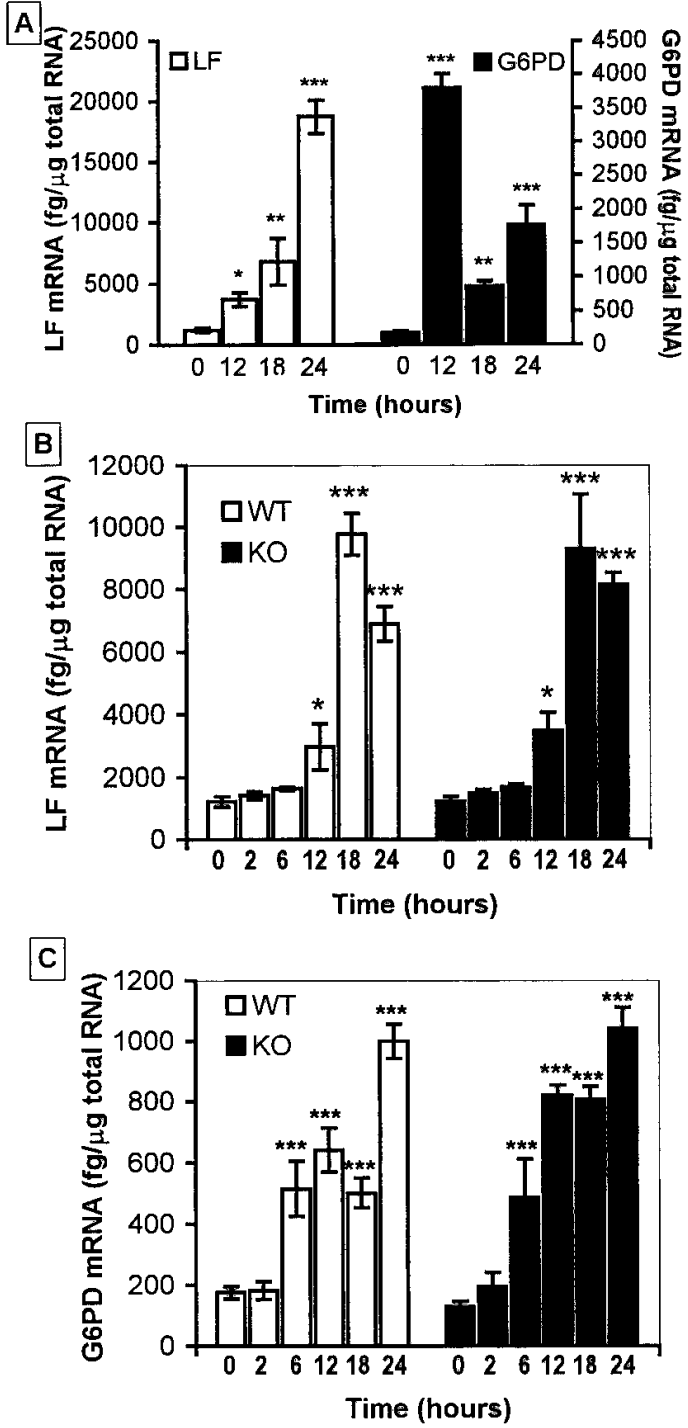

FIG. 2. A, LF and G6PD gene expression in WT mice after a single injection of $10 \mu \mathrm{g} / \mathrm{kg} \mathrm{E}_{2}$. Animals were killed at different times after injection $(12,18$, and $24 \mathrm{~h})$. RNA quantitation was done by quantitative RT-PCR and the result obtained as fg/ $\mu \mathrm{g}$ total RNA. $\mathrm{n}=2-11$ animals per group. B, Time-course study of methoxychlor effects on LF mRNA concentrations in WT and ER $\alpha \mathrm{KO}$ mice. Animals were given a single injection of $15 \mathrm{mg} / \mathrm{kg} \mathrm{Mxc}$ and were killed 2, 6, 12, 18, and $24 \mathrm{~h}$ after treatment. $\mathrm{n}=3-11$ animals per group. C, Time-course study of methoxychlor effects on G6PD mRNA concentrations in WT and $\mathbf{E R} \alpha \mathrm{KO}$ mice. Animals were given a single injection of $15 \mathrm{mg} / \mathrm{kg}$ Mxc and were killed 2,6,12,18, and $24 \mathrm{~h}$ after treatment. $\mathrm{n}=2-10$ animals per group. All data represent mean $\pm \mathrm{SE}$. ${ }^{*}, P<0.05 \mathrm{vs}$. control treatment; ${ }^{* *}, P<0.01$ us. control treatment; ***, $P<0.001$ vs. control treatment.

dependent manner in WT mice, up to $30 \mathrm{mg} / \mathrm{kg}$ (Fig. 3A). Little effect was seen before the $5.7-\mathrm{mg} / \mathrm{kg}$ dose, after which message concentrations rose to a peak at $30 \mathrm{mg} / \mathrm{kg}$ and then declined. The $30-\mathrm{mg} / \mathrm{kg}$ dose seemed to be a maximally effective dose in WT mice. In WT animals, a sharper decline in message was seen, starting from $45 \mathrm{mg} / \mathrm{kg}$; and a gradual fall was seen at the $60-\mathrm{mg} / \mathrm{kg}$ dose. The scenario in the $\mathrm{ER} \alpha \mathrm{KO}$ mouse was quite different. Although the $1.8-\mathrm{mg} / \mathrm{kg}$ dose was ineffective, the next lower doses $(3.75,5.7$, and 7.5

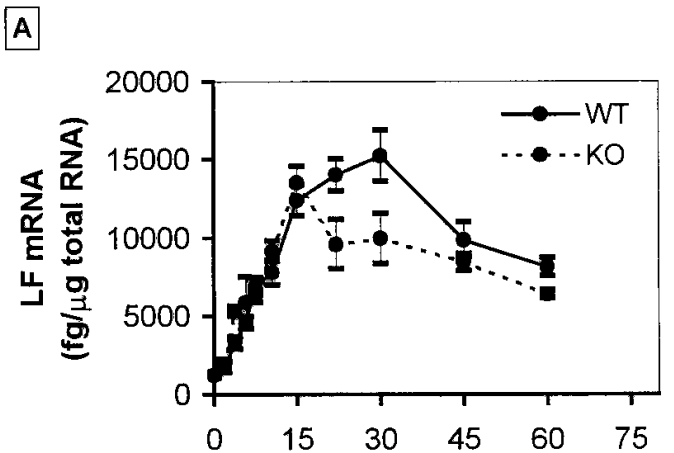

Dose (mg/kg body weight)

B

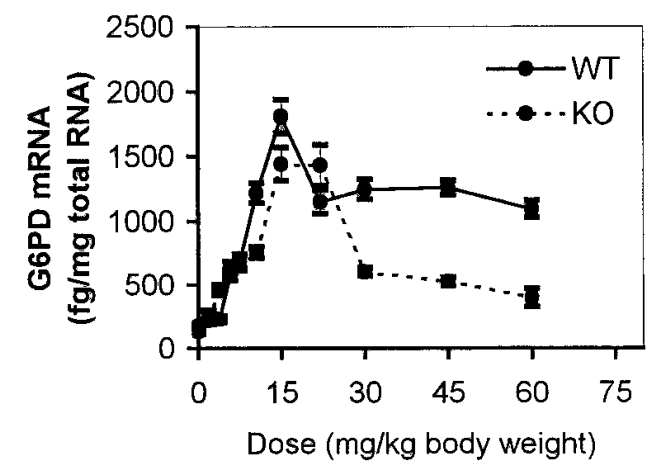

FIG. 3. Dose-response study of methoxychlor effects on LF (A) and G6PD (B) mRNA concentrations in WT and ER $\alpha \mathrm{KO}$ mice. Animals were injected with different doses of $\mathrm{Mxc}$ in two consecutive injections, $6 \mathrm{~h}$ apart, and were killed $12 \mathrm{~h}$ after the final injection. Data represent mean $\pm \operatorname{SE}(n=2-13$ animals per group for $L F ; n=2-10$ animals per group for $\mathrm{G} 6 \mathrm{PD}$ ).

$\mathrm{mg} / \mathrm{kg}$ ) gave similar magnitude responses (about 4.5 -fold increase), forming a short plateau. After this plateau, a further stimulation was seen at the $10-\mathrm{mg} / \mathrm{kg}$ dose (7-fold), with a sharper increase (up to 10.5 -fold) at $15 \mathrm{mg} / \mathrm{kg}$; message concentrations declined after this dose, down to 4.8 -fold at 60 $\mathrm{mg} / \mathrm{kg}$.

\section{Effects of different doses of Mxc on uterine G6PD mRNA concentrations}

The responsiveness to Mxc of G6PD followed a pattern almost similar to that of LF, in terms of dose response (Fig. 3B). Although the lower (1.8- and 3.75-mg/ $/ \mathrm{kg}$ ) doses seemed ineffective in WT animals, injection with Mxc at the higher doses induced increases in G6PD mRNA concentrations in WT animals in a dose-dependent manner, rising to a maximum-fold increase at $15 \mathrm{mg} / \mathrm{kg}$. After this point, a decrease in mRNA concentrations was seen, although fold increase did not drop further and remained at around 7 -fold at the higher doses $(22,30$, and $60 \mathrm{mg} / \mathrm{kg}$ ).

$\mathrm{ER} \alpha \mathrm{KO}$ mice again showed a small plateau response at the lower doses (3.5-fold at $3.75 \mathrm{mg} / \mathrm{kg}$, and 5-fold at 5.7 and 7.5 $\mathrm{mg} / \mathrm{kg}$ ). A further increase in message concentration was seen at $10.5 \mathrm{mg} / \mathrm{kg}$ (5.9-fold), and a sharp increase at $15 \mathrm{mg}$ (12-fold) was observed that was maintained at $22 \mathrm{mg}$ (11fold). Nevertheless, as seen for LF, a fall in G6PD mRNA 
concentration was seen at $30 \mathrm{mg}$ (4.6-fold), $45 \mathrm{mg}$ (4-fold), and $60 \mathrm{mg}$ (3-fold).

\section{Effect of estradiol $17 \beta$ and ICI on Mxc-induced increases in LF mRNA concentrations}

This study was carried out to check whether competitive pretreatment with estrogen or antiestrogen would inhibit the Mxc-induced stimulation of LF (Fig. 4A) and G6PD (Fig. 4B) mRNAs. Pretreatment with $E_{2}$ at $10 \mu \mathrm{g} / \mathrm{kg}$ did not inhibit, but did reduce, the magnitude of the $\mathrm{Mxc}$-induced increases in LF mRNA concentrations in both WT and ER $\alpha \mathrm{KO}$ mice (Fig. 4A). The fold increase was reduced from 10- to 7-fold in WT mice and from 10- to 8-fold in ER $\alpha \mathrm{KO}$ animals. $\mathrm{E}_{2}$ alone, at doses of 10 and $100 \mu \mathrm{g} / \mathrm{kg}$, gave 14.6 -fold and 16.4-fold increases, respectively, in WT mice; whereas no responses were observed in $\mathrm{ER} \alpha \mathrm{KO}$ mice other than a very

A

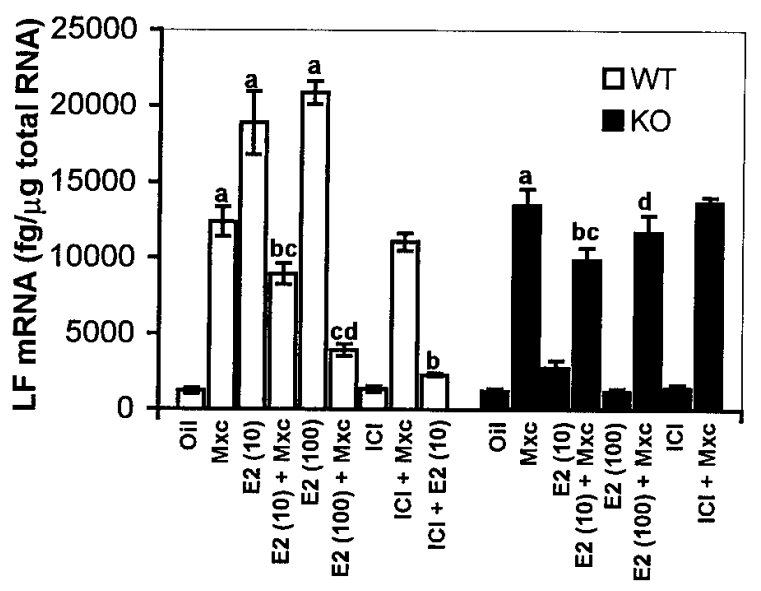

B

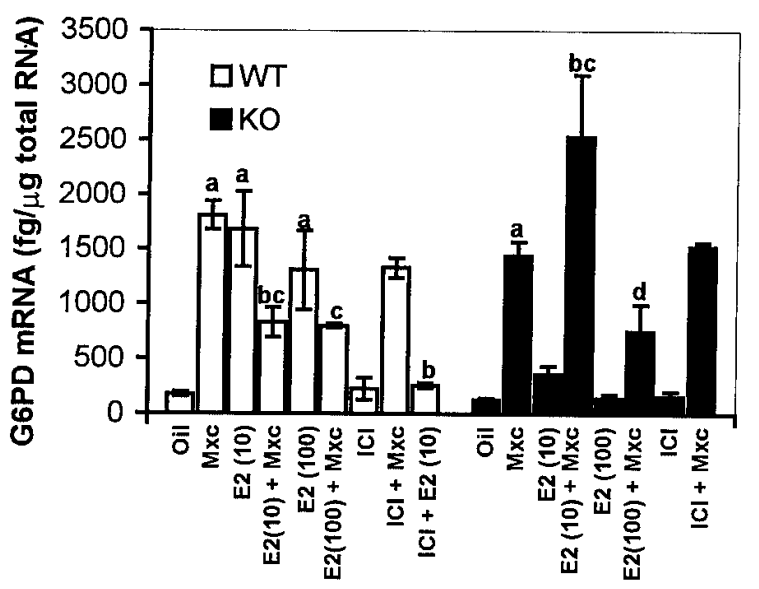

FIG. 4. Effects of $E_{2}$ and ICI on Mxc-induced effects on LF (A) and G6PD (B) mRNA concentrations. Animals were injected with oil, Mxc at $15 \mathrm{mg} / \mathrm{kg}, \mathrm{E}_{2}$ at $10 \mu \mathrm{g} / \mathrm{kg}\left(\mathrm{E}_{2} 10\right)$ or $100 \mu \mathrm{g} / \mathrm{kg}\left(\mathrm{E}_{2} 100\right)$, or ICI at 15 $\mathrm{mg} / \mathrm{kg}$. For dual treatments, $\mathrm{E}_{2}$ or ICI was injected $30 \mathrm{~min}$ before injecting Mxc. All treatments were given as two series of injections, $6 \mathrm{~h}$ apart, and the animals were killed $12 \mathrm{~h}$ after the final injection. Data represent mean $\pm S E(n=2-13$ animals per group for $L F ; n=$ 2-13 animals per group for G6PD). Significance (at $P<0.05$ or greater): $\mathbf{a}$, value significant vs. oil; $\mathbf{b}$, value significant vs. $\mathrm{E}_{2}(10$ $\mu \mathrm{g} / \mathrm{kg})$; c, value significant $v s$. Mxc; d, value significant vs. $\mathrm{E}_{2}(100$ $\mu \mathrm{g} / \mathrm{kg})$. slight (3-fold) stimulation at $10 \mu \mathrm{g} / \mathrm{kg}$. Pretreatment with $\mathrm{E}_{2}$ at $100 \mu \mathrm{g} / \mathrm{kg}$ considerably reduced the Mxc-induced LF response (from 10- to 2.7-fold increase) in WT mice. The ER $\alpha \mathrm{KO}$ mice showed magnitudes of response almost similar to those of Mxc, both with and without pretreatment with either dose of $E_{2}$, although the lower dose of $E_{2}$ seemed to inhibit the Mxc-induced effect (from 10.5- to 8-fold). Treatment with the antiestrogen ICI alone, at a dose of $15 \mathrm{mg} / \mathrm{kg}$, had no effect on LF mRNA concentrations. Pretreatment with ICI had no effect on the Mxc-induced response in WT or $\mathrm{ER} \alpha \mathrm{KO}$ mice, but the same dose did inhibit the response to estradiol in WT mice.

\section{Effect of estradiol $17 \beta$ and ICI on Mxc-induced increases in G6PD mRNA concentrations}

Pretreatment with $\mathrm{E}_{2}(10 \mu \mathrm{g} / \mathrm{kg})$ in WT mice reduced the Mxc-induced increases in G6PD mRNA concentrations from 10- to 4.5 -fold, consistent with the LF results (Fig. 4B). In contrast, this dose of $\mathrm{E}_{2}$ did not inhibit the Mxc-induced increases in G6PD mRNA concentrations in the ER $\alpha \mathrm{KO}$ mouse and, instead, had an additive effect. However, the higher, $100-\mu \mathrm{g} / \mathrm{kg}$ E2 dose led to a partial reduction of the Mxc-induced response in both subject groups (from 10- to 5-fold in the WT, and 11- to 6-fold in the ER $\alpha \mathrm{KO}$ ). The response pattern of G6PD message to ICI was similar to that for LF. ICI did not have any effect when injected alone, inhibited the $\mathrm{E}_{2}$-induced response seen in WT mice, but did not inhibit Mxc-induced G6PD response in WT or ER $\alpha \mathrm{KO}$ mice.

\section{Discussion}

For screening of environmental estrogens in the future, it will be important to recognize all the molecular pathways through which these compounds may be working. $\mathrm{E}_{2}$-induced activation of the LF gene has been shown to be mediated through ER $\alpha$ by an imperfect palindromic ERE in the 5 'flanking region of the LF gene (28); less is known about G6PD activation. To determine whether uterine responses to Mxc were also mediated through $\mathrm{ER} \alpha$, we compared the effects of these agents on uterine LF and G6PD mRNA concentrations in ovariectomized $\mathrm{ER} \alpha \mathrm{KO}$ and WT mice by using quantitative RT-PCR.

We show here that, in the WT mouse, Mxc (like $\left.\mathrm{E}_{2}\right)$ stimulated increases in uterine LF and G6PD mRNA in a saturable, dose-dependent manner and that $E_{2}$-stimulated increases were dramatically reduced by competitive pretreatment with the pure antiestrogen ICI. In contrast, the increases in mRNA concentrations induced by Mxc were not inhibited by this antiestrogen. Competitive pretreatment with $E_{2}$, at $10 \mu \mathrm{g} / \mathrm{kg}$, had only a partially inhibitory effect on the Mxc-induced responses, and the antiestrogen alone did not influence the concentrations of uterine LF or G6PD mRNA. Collectively, these results indicate that, under normal conditions, the WT uterus responds to both $M \times c$ and $E_{2}$, in terms of increased LF and G6PD mRNA concentrations. Moreover, the lack of ICI inhibition of Mxc-induced uterine LF and G6PD mRNA accumulation, and their only-partial inhibition by $E_{2}$, suggested that $M x c$ can act through an additional independent signaling pathway not involving 
ER $\alpha$ or ER $\beta$. We confirmed these results by using ovariectomized $\mathrm{ER} \alpha \mathrm{KO}$ mice.

In the ER $\alpha \mathrm{KO}$ mouse, we show that $\mathrm{E}_{2}$ was ineffective at stimulating marked increases in uterine LF or G6PD mRNA concentrations, agreeing with work by Das et al. (25). Mxc, however, did stimulate both LF and G6PD mRNA, in a saturable and dose-dependent manner, indicative of a receptor-mediated mechanism of action. This increase in uterine LF and G6PD mRNA concentrations, induced by Mxc, was not suppressed by competitive pretreatment with $E_{2}$ or $\mathrm{ICI}$ in the manner seen in WT animals, thus confirming that Mxc can work through a non-ER $\alpha$ and non-ER $\beta$ mechanism. It is interesting to note that both LF and G6PD mRNA concentrations were stimulated equally in WT and $\mathrm{ER} \alpha \mathrm{KO}$ mice, suggesting that the predominant pathway for Mxc action on these mRNAs is not via ER $\alpha$. Again, the lack of inhibition by ICI or $E_{2}$ of Mxc-induced effects indicates that ER $\alpha$ and $E R \beta$ are minimally involved in mediating the effects of Mxc on LF and G6PD mRNA concentrations. In support of this, it should be noted that the concentrations of ER $\beta$ are remarkably low, in comparison with ER $\alpha$, in the WT and ER $\alpha \mathrm{KO}$ mouse uterus (31).

Taken together, these uterine responses to $\mathrm{Mxc}$ in the mouse clearly establish the presence of a pathway that is not mediated via the classical ER $\alpha$ or ER $\beta$ but, instead, through an additional signaling pathway. However, although the saturable dose responses are indicative of a receptor-mediated mechanism, this pathway may not necessarily involve an additional ER (such as an ER $\gamma$ ). It is possible, for example, that Mxc effects are mediated via a membrane receptor or another nuclear receptor.

Although the molecular pathway(s) by which Mxc alters these estrogen-sensitive uterine mRNA concentrations has yet to be characterized, several possibilities can be ruled out. First, although $\mathrm{ER} \alpha \mathrm{KO}$ mice lack full-length $\mathrm{ER} \alpha$, they may still have alternatively spliced forms of $\mathrm{ER} \alpha$. The existence of alternatively spliced forms of ER $\alpha$ that contain the ER ligandbinding domain has recently been documented, either with sequence changes upstream of the exon $5 / 6$ boundary in rat pituitary or lacking exon 5 in rat brain and human smooth muscle cells (32-34). Second, it is possible that effects of estrogenic ligands in ER $\alpha \mathrm{KO}$ mice could be mediated by different ER subtypes, such as ER $\beta$ or its alternatively spliced forms (35-37). However, it is known that $E_{2}$ and antiestrogens bind to both $E R \alpha$ and $E R \beta$ ligand-binding domains (12). Our observations demonstrate that $E_{2}$ has little or no effect on ER $\alpha$ KO uterine LF and G6PD mRNA concentrations, and that neither $\mathrm{E}_{2}$ nor ICI markedly inhibits Mxc-induced increases in uterine LF and G6PD mRNAs in ER $\alpha$ KO mice. This lack of inhibition suggests that the effects of this xenoestrogen on the uterine LF and G6PD genes are not mediated via the ligand-binding domains of ER $\alpha$ or ER $\beta$. A third factor to consider is that the LF gene has been shown to have two promoter regions (38), and it is possible that Mxc may exert its effects on LF and G6PD through promoter regions on these genes that differ from those used by $\mathrm{E}_{2}$.

One important factor to consider is that mRNA concentrations, at any given point in time, represent a balance between synthesis and degradation. Estrogen has been shown to regulate the stability of specific mRNAs (39), and the possibility remains that xenoestrogens may regulate mRNA concentrations through altering expression or via effects on stabilization or destabilization of mRNAs.

The relative pharmacokinetics of $\mathrm{Mxc}$ as a pro-drug and $\mathrm{E}_{2}$ and ICI as drugs might be considered to present technical difficulties for this study, especially in competition experiments. However, we do not believe that this is likely to be a problem, because our dose-response times ( $12 \mathrm{~h}$ after last dose) are short, and the inhibitory effects of ICI on estradiol are evident in the WT controls throughout the time course of our experiments. From the controls, it is clear that ICI is still present and would be capable of inhibiting $\mathrm{Mxc}$ if it were working through either an ER $\alpha$ or ER $\beta$ ligand-binding domain. In addition, it has been shown that ICI is a comparatively long-acting drug (days longer than tamoxifen), with sustained antiestrogenic effects from a single injection in oil that last at least 3 weeks (39a). Therefore, even if it takes hours, or even a day, for Mxc to be metabolized into an active form, the antiestrogenic effect of ICI would still exist when the active form of Mxc was generated. From this, it is clear that ICI is still present and capable of inhibiting the pro-drug Mxc or its metabolites if it were working through either a ER $\alpha$ or ER $\beta$ ligand-binding domain.

It has been suggested (40) that one way xenobiotics disrupt endocrine function is by interfering with the ability of natural ligands to bind receptors and/or binding proteins, perhaps at multiple levels of activation. Mxc is known to be active in vivo, acting as a proestrogen, which requires metabolism for estrogenic effectiveness (41). Mxc's metabolites have been less extensively studied than Mxc itself, but Gaido et al. (42) have reported that HPTE, thought to be the active in vivo metabolite, acts as an agonist for $\mathrm{ER} \alpha$ but as an antagonist for ER $\beta$. Katzenellenbogen et al. (43) have also reported finding ER ligands that are full agonists via $\mathrm{ER} \alpha$ but antagonists via $E R \beta$, as well as one gene, quinone reductase, whose activity is up-regulated by antiestrogens acting through $\mathrm{ER} \alpha$ and ER $\beta$. This mixed agonist/antagonist function has also been reported for other compounds. The antiestrogen hydroxytamoxifen has mixed agonist/antagonist activity through $\mathrm{ER} \alpha$, depending on the tissue and gene $(44,45)$, and can exert synergistic effects when combined with $\mathrm{E}_{2}(46)$.

We had expected that, because both $\mathrm{Mxc}$ and $\mathrm{E}_{2}$ are thought to act through ER $\alpha$, their effects would be additive, but this was not seen. It is possible that, in the WT uterus (that is, in the presence of $\mathrm{ER} \alpha$ ), Mxc may act as a mixed agonist/ antagonist to $E_{2}$ action by partial binding with $E R \alpha$, as well as acting through another pathway. These interactions may, in some way, account for the unexpected decrease in Mxc activity we observed in WT animals when $E_{2}$ was added. It is also possible that the receptor used by Mxc is an ER $\alpha$ repressor.

The additive effect of $\mathrm{Mxc}$, with low doses of $\mathrm{E}_{2}$, in the $\mathrm{ER} \alpha \mathrm{KO}$ mouse, was also unexpected. Although the error bar for these samples was unusually large, the decrease in Mxcinduced increases in G6PD mRNA levels in the presence of $\mathrm{E}_{2}(100 \mu \mathrm{g} / \mathrm{kg})$ was not statistically different from Mxc alone. Clearly, this in vivo system is complex, and it involves potential interactions of $\mathrm{ER} \alpha, \mathrm{ER} \beta$, and $\mathrm{ER} \alpha$-ER $\beta$ heterodimers, as well as interactions between these ERs and the additional receptor used by Mxc. Further, there is likely to be some 
degree of cross-talk between $\operatorname{ER} \alpha / \mathrm{ER} \beta$ and the Mxc-signaling pathway. It is also possible that there are activators or repressors that are important in the control of ER function whose normal actions are altered by the lack of ER $\alpha$ in the $\mathrm{ER} \alpha \mathrm{KO}$ mouse uterus.

One interesting feature was the differing time course of Mxc-induced responses for G6PD and LF mRNA. Mxc stimulated both LF and G6PD mRNA concentrations in a dosedependent fashion, but the increase in LF message concentrations was slower than that of G6PD (increases in LF mRNA concentrations were not seen until $12 \mathrm{~h}$, whereas increases in G6PD mRNA concentrations were seen at around $6 \mathrm{~h}$ ). This is similar to the findings of Curtis et al. (47), examining the effects of DES and its metabolites, and suggests that Mxc acts on these two genes through two different mechanisms, one more rapid than the other. Another fact that suggests independence of the two pathways is that, for G6PD (but not LF) mRNA concentrations, the lower dose of $\mathrm{E}_{2}(10$ $\mu \mathrm{g} / \mathrm{kg}$ ) seemed to be additive with $\mathrm{Mxc}$, in the $\mathrm{ER} \alpha \mathrm{KO}$ mouse. Additive or synergistic actions of $E_{2}$ are not unknown. and have been reported elsewhere, with testosterone in prostate growth (48), with kepone in uterus (49), and with isomers of DDT in MCF-7 cells (50). Finally, in these experiments, there is also a clear difference in how LF and G6PD are regulated in the presence of E2 and Mxc together. Understanding of the molecular cause of these differences awaits a detailed comparative analysis of the LF and G6PD promoter regions in in vitro transcriptional reporter assays.

In summary, our findings in ER $\alpha \mathrm{KO}$ mice demonstrate that a xenoestrogen can up-regulate the expression of two estrogen-responsive genes in the uterus, via one or more pathways that do not seem to involve $\mathrm{ER} \alpha$ or ER $\beta$. Currently, there is much interest in xenoestrogens and other environmental endocrine disrupters because of their potential adverse effects on human and animal health. Further characterization of this novel pathway will enhance our understanding, not only of xenoestrogen action but also of diverse steroid hormone and endocrine disrupter actions in target organs.

\section{Acknowledgments}

The authors are thankful to Drs. S. K. Das and S. K. Dey (of the University of Kansas Medical Center, Kansas City) for their kind gift of the LF competitor template. The authors also thank Professor R. Michael Roberts for his earnest cooperation and constant encouragement, Dr. Alan Ealy for helping in statistical analysis, and Dr. Ed Curran for critically reviewing the manuscript.

\section{References}

1. Welch RM, Levin W, Conney AH 1969 Estrogenic action of DDT and its analogs. Toxicol Appl Pharmacol 14:358-367

2. Eroschenko VP, Rourke AW, Sims WF 1996 Estradiol or methoxychlor stimulates estrogen receptor (ER) expression in uteri. Reprod Toxicol 10:265-271

3. Swartz WJ, Wink CS, Johnson WD 1994 Response of adult murine uterine epithelium to $50 \%$ methoxychlor. Reprod Toxicol 8:81-87

4. Bulger WH, Muccitelli RM, Kupfer D 1978 Studies on the in vivo and in vitro estrogenic activities of methoxychlor and its metabolites. Role of hepatic monooxygenase in methoxychlor activation. Biochem Pharmacol 27:2417-2423

5. Cummings AM, Metcalf JL 1994 Mechanisms of the stimulation of rat uterine peroxidase activity by methoxychlor. Reprod Toxicol 8:477-486

6. Walters LM, Rourke AW, Eroschenko VP 1993 Purified methoxychlor stimulates the reproductive tract in immature female mice. Reprod Toxicol 7:599-606

7. Metcalf JL, Law SC, Cummings AM 1996 Methoxychlor mimics the action of
$17 \beta$ estradiol on induction of uterine epidermal growth factor receptors in immature female rats. Reprod Toxicol 10:393-399

8. Kuiper GGJM, Enmark E, Pelto-Huikko M, Nilsson S, Gustafsson JA 1996 Cloning of a novel estrogen receptor expressed in rat prostate and ovary. Proc Natl Acad Sci USA 93:5925-5930

9. Mosselman S, Polman J, Dijkema R 1996 ER- $\beta$ : identification and characterization of a novel human estrogen receptor. FEBS Lett 392:49-53

10. Kuiper GGJM, Carlsson B, Grandien K, Enmark E, Haggblad J, Nilsson S, Gustafsson J-A 1997 Comparison of the ligand binding specificity and transcript tissue distribution of estrogen receptors $\alpha$ and $\beta$. Endocrinology 138:863-870

11. Hall DL, Payne LA, Putman JM, Huet-Hudson YM 1997 Effect of methoxychlor on implantation and embryo development in the mouse. Reprod Toxicol 11:703-708

12. Kuiper GJM, Lemmen J, Carlsson B, Corton JC, Safe SH, van der Saag PT, van der Burg B, Gustafsson J-A 1998 Interaction of estrogenic chemicals and phytoestrogens with estrogen receptor $\beta$. Endocrinology 139:4252-4263

13. Bulger WH, Muccitelli RM, Kupfer D 1978 Interactions of methoxychlor, methoxychlor base-soluble contaminant, and 2,2-bis(p-hydroxyphenyl)-1,1,1trichloroethane with rat uterine estrogen receptor. J Toxicol Environ Health $4: 881-893$

14. vom Saal FS, Nagel SC, Palanza P, Boechler M, Parmigiani S, Welshons WV 1995 Estrogenic pesticides: binding relative to estradiol in MCF-7 cells and effects of exposure during fetal life on subsequent territorial behaviour in male mice. Toxicol Lett 77:343-350

15. Longnecker MP, Rogan WJ, Lucier G 1997 The human health effects of DDT (dichlorodiphenyltrichloroethane) and PCBS (polychlorinated biphenyls) and an overview of organochlorines in public health. Annu Rev Public Health 18:211-244

16. Bitman J, Cecil HC 1970 Estrogenic activity of DDT analogues and polychlorinated biphenyls. J Agric Food Chem 18:1108-1112

17. Guzelian PS 1982 Comparative toxicology of chlorodecone (kepone) in humans and experimental animals. Annu Rev Pharmacol Toxicol 22:89-113

18. Gellert RJ, Heinrichs WL, Swerdloff RS 1972 DDT homologues: estrogen-like effects on the vagina, uterus and pituitary of the rat. Endocrinology 91:1095-1100

19. Gellert RJ 1978 Kepone, mirex, dieldrin, and aldrin: estrogenic activity and the induction of persistent vaginal estrus and anovulation in rats following neonatal treatment. Environ Res 16:131-138

20. Kelce WR, Stone CR, Laws SC, Gray LE, Kemppainen JA, Wilson EM 1995 Persistent DDT metabolite $p, p^{\prime}-$ DDE is a potent androgen receptor antagonist. Nature 375:581-585

21. Newbold R 1995 Cellular and molecular effects of developmental exposure to diethylstilbestrol: implications for other environmental estrogens. Environ Health Perspect 103:83-87

22. McLachlan JA, Korach KS 1995 Symposium on estrogen in the environment III. Environ Health Perspect 103:3-4

23. Safe SH 1995 Environmental and dietary estrogens and human health: is there a problem? Environ Health Perspect 103:346-351

24. Lubahn DB, Moyer JS, Golding TS, Couse JF, Korach KS, Smithies O 1993 Alteration of reproductive function but not prenatal sexual development after insertional disruption of the mouse estrogen receptor gene. Proc Natl Acad Sci USA 90:11162-11166

25. Das SK, Taylor JA, Korach KS, Paria BC, Dey SK, Lubahn DB 1997 Estrogenic responses in estrogen receptor- $\alpha$ deficient mice reveal a distinct estrogen signaling pathway. Proc Natl Acad Sci USA 94:12786-12791

26. Das SK, Tan J, Johnson DC, Day SK 1998 Differential spatiotemporal regulation of lactoferrin and progesterone receptor gene in the mouse uterus by primary estrogen, catechol estrogen and xenoestrogen. Endocrinology 139:2905-2915

27. Pentecost BT, Teng CT 1987 Lactotransferrin is the major estrogen inducible protein of mouse uterine secretions. J Biol Chem 262:10134-10139

28. Liu Y, Teng CT 1992 Estrogen response module of the mouse lactoferrin gene contains overlapping chicken ovalbumin upstream promoter transcription factor and estrogen receptor binding elements. Mol Endocrinol 6:355-364

29. Couse JF, Curtis SW, Washburn TF, Lindzey J, Golding TS, Lubahn DB, Smithies O, Korach KS 1995 Analysis of transcription and estrogen insensitivity in female mouse after targeted disruption of the estrogen receptor gene. Mol Endocrinol 9:1441-1454

30. Ibim SEM, Randall R, Han P, Musey PI 1989 Modulation of hepatic glucose 6-phosphate dehydrogenase activity in male and female rats by estrogen. Life Sci 45:1559-1565

31. Couse JF, Lindzey J, Grandien K, Gustafsson J-A, Korach KS 1997 Tissue distribution and quantitative analysis of estrogen receptor- $\alpha(\mathrm{ER} \alpha)$ and estrogen receptor- $\beta$ (ER $\beta)$ messenger ribonucleic acid in the wild-type and ER $\alpha$ knockout mouse. Endocrinology 138:4613-4621

32. Skipper JK, Young LJ, Bergeron JM, Tetzlaff MT, Osborm CT, Crews D 1993 Identification of an isoform of the estrogen receptor messenger RNA lacking exon four and present in the brain. Proc Natl Acad Sci USA 90:7172-7175

33. Friend KE, Ang LW, Shupnik MA 1995 Estrogen regulates the expression of several different estrogen receptor mRNA isoforms in rat pituitary. Proc Natl Acad Sci USA 92:4367-4371 
34. Karas RH, Baur WE, van Eickles M, Mendlson ME 1995 Human vascular smooth muscle cells express an estrogen receptor isoform. FEBS Let 377:103-108

35. Chu S, Fuller P 1997 Identification of a spliced variant of rat estrogen receptor beta gene. Mol Cell Endocrinol 132:195-199

36. Moore JT, McKee DD, Slentz-Lesler K, Moore LB, Jones SA, Horne EL, Su JL, Kliewer SA, Lehman JM, Wilson TM 1998 Cloning and characterization of human estrogen receptor $\beta$ isoforms. Biochem Biophys Res Commun 247:75-78

37. Maruyama K, Endoh $H$, Sasaki-Iwaoka H, Kanou $H$, Shimaya E, Hashimoto S, Kata S, Kawashima H 1998 A novel form of rat estrogen receptor beta with 18 amino acid insertion in the ligand binding domain as a putative dominant negative regulator of estrogen action. Biochem Biophys Res Commun 246:142-147

38. Siebert PD, Huang BC 1997 Identification of an alternative form of human lactoferrin mRNA that is expressed differently in normal tissue and tumorderived cell lines. Proc Natl Acad Sci USA 94:2198-2203

39. Blume JE, Shapiro DJ 1989 Ribosome loading but not protein synthesis is required for estrogen stabilization of Xenopus laevis vitellogenin mRNA. Nucleic Acids Res 17:9003-9014

39a.Wakeling AE, Dukes M, Bowler J 1991 A potent specific antiestrogen with clinical potential. Cancer Res 51:3867-3873

40. Danzo B 1997 Environmental xenobiotics may disrupt normal endocrine function by interfering with the binding of physiological ligands to steroid receptors and binding proteins. Environ Health Perspect 105:294-301

41. Kupfer D, Bulger WH 1987 Metabolic activation of pesticides with proestrogenic activity. Fed Proc 46:1864-1869

42. Gaido KW, Leonard LS, Maness SC, McDonnell DP, Galluzzo J, Seville B, Safe S, Differential interaction of the methoxychlor metabolite, HPTE, with estrogen receptors $\alpha$ and $\beta$. Program of the 80th Annual Meeting of The Endocrine Society, New Orleans, LA, 1998 (Abstract OR 14-2), p 71

43. Katzenellenbogen BS, Montano MM, Ekena K, Lazennec G, Ediger T, McInerny E, Choi I, Sun J, Weis K, Katzenellenbogen JA, Estrogen receptor pharmacology. Program of the 80th Annual Meeting of The Endocrine Society, New Orleans, LA, 1998 (Abstract S39-1), pp 42-43

44. Watanabe T, Inoue S, Ishii Y, Hiroi H, Ikeda K, Orimo A, Muramatsu M 1997 Agonistic effect of tamoxifen is dependent on cell type, ERE-promoter context, and estrogen receptor subtype: functional difference between estrogen receptors $\alpha$ and $\beta$. Biochem Biophys Res Commun 236:140-145

45. Somjen D, Waisman A, Kaye AM 1996 Tissue selective action of tamoxifen methiodide, raloxifene and tamoxifen on creatine kinase B activity in vitro and in vizo. J Steroid Biochem Mol Biol 59:389-396

46. Ghosh D, Ray AK 1993 Subcellular action of estradiol-17 beta in a freshwater prawn, Macrobrachium rosenbergii. Gen Comp Endocrinol 90:274-281

47. Curtis SW, Shi H, Teng C, Korach KS 1997 Promoter and species specific differential estrogen-mediated gene transcription in the uterus and cultured cells using structurally altered agonists. J Mol Endocrinol 18:203-211

48. Suzuki K, Ito K, Suzuki T, Honma S, Yamanaka H 1995 Synergistic effects of estrogen and androgen on the prostate: effects of estrogen on androgen and estrogen receptors, BrdU uptake, immunohistochemical study of AR, and responses to antiandrogens. Prostate 26:151-163

49. Johnson DC 1996 Estradiol-chlordecone (kepone) interactions: additive effect of combinations for uterotrophic and embryo implantation functions. Toxicol Lett 89:57-64

50. Chen CW, Hurd C, Vorojeikina DP, Amold SF, Notides AC 1997 Transcriptional activation of the human estrogen receptor by DDT isomers and metabolites in yeast and MCF-7 cells. Biochem Pharmacol 53:1161-1172 